\title{
Depth and Degree of Melting of Komatiites
}

\author{
Claude Herzberg \\ Department of Geological Sciences, Rutgers University, New Brunswick, New Jersey \\ Mineral Physics Institute, State University of New York, Stony Brook, New York
}

\begin{abstract}
High pressure melting experiments have permitted new constraints to be placed on the depth and degree of partial melting of komatiites. Komatiites from Gorgona Island were formed by relatively low degrees of pseudoinvariant melting $(<30 \%)$ involving $\mathrm{L}+\mathrm{Ol}+\mathrm{Opx}+\mathrm{Cpx}+\mathrm{Gt}$ on the solidus at $40 \mathrm{kbar}$, about 130 $\mathrm{km}$ depth. Munro-type komatiites were separated from a harzburgite residue $(\mathrm{L}+\mathrm{Ol}+\mathrm{Opx})$ at pressures that are poorly constrained, but were probably around $50 \mathrm{kbar}$, about $165 \mathrm{~km}$ depth; the degree of partial melting was $<40 \%$. Komatiites from the Barberton Mountain Land were formed by high degrees $(\sim 50 \%)$ of pseudoinvariant melting $(\mathrm{L}+\mathrm{Ol}+\mathrm{Gt}+\mathrm{Cpx})$ of fertile mantle peridotite in the 80- to 100-kbar range, about 260- to 330- km depth. Secular variations in the geochemistry of komatiites could have formed in response to a reduction in the temperature and pressure of melting with time. The $3.5 \mathrm{Ga}$ Barberton komatiites and the 2.7 Ga Munro-type komatiites could have formed in plumes that were hotter than the present-day mantle by $500^{\circ}$ and $300^{\circ}$, respectively. When excess temperatures are this size, melting is deeper and volcanism changes from basaltic to komatiitic. The komatiites from Gorgona Island, which are Mesozoic in age, may be representative of komatiites that are predicted to occur in oceanic plateaus of Cretaceous age throughout the Pacific [Storey et al., 1991].
\end{abstract}

\section{INTRODUCTION}

Komatiites are high $\mathrm{MgO}$ volcanic rocks that can be roughly explained by high degrees of melting of mantle peridotite, typically 50 to $100 \%$ [e.g., Viljoen and Viljoen, 1969; Green, 1972; Brooks and Hart, 1974; Cawthorn and Strong, 1974; Nesbitt and Sun, 1976; Bickle et al., 1977; Nisbet and Walker, 1982; Hess, 1990; Miller et al., 1991b]. But this interpretation is neither unique nor without its difficulties. Arndt [1977] pointed out the problem of forming komatiites in a single stage because basaltic melts are buoyant and they would segregate and drain from the source region before melting reached 20 to $30 \%$. Nisbet and Walker [1982] noted that this problem disappears at high pressures because olivine and komatiitic magmas are expected to have similar densities. The problem also disappears in the models of O'Hara et al. [1975] and Howells et al. [1975], who pointed out that initial melting at high pressures was likely to yield in a single stage komatiites instead of basalts. This high pressure origin has received considerable support from experimental data in the $100-\mathrm{kbar}$ range [Herzberg and O'Hara, 1985; Takahashi, 1986; Wei et al., 1990; Herzberg et al., 1990].

Nesbitt et al. [1979] noted that wide variations exist in contents of $\mathrm{CaO}, \mathrm{Al}_{2} \mathrm{O}_{3}$, and $\mathrm{TiO}_{2}$, and subdivided komatiites into alumina-depleted and -undepleted types. If they were formed by very high degrees of melting, these differences can only be explained by differences in the composition of the source region [Cawthorn and Strong, 1974; Jahn et al. , 1980; Herzberg and Ohtani, 1988; Anderson, 1989]. However, Arndt [1986] and Fujii et al. [1989] noted that these differences may not reflect the source, but instead are phase equilibrium-controlled at very high pressures. In order to test these possibilities, melting experiments have been run on compositions with a wide

\section{Copyright 1992 by the American Geophysical Union.}

Paper number $91 \mathrm{JB} 03066$

$0148-0227 / 92 / 91 \mathrm{JB}-03066 \$ 05.00$ range of $\mathrm{CaO}$ and $\mathrm{Al}_{2} \mathrm{O}_{3}$ contents in the 80- to $160-\mathrm{kbar}$ range. A calibration has been made of the effect of pressure on $\mathrm{CaO} /\left(\mathrm{CaO}+\mathrm{Al}_{2} \mathrm{O}_{3}\right)$ and $\mathrm{MgO}$ in komatiitic liquids formed on the solidus, and an examination has been made of the effect of $\mathrm{FeO}$. It is now possible to simulate the melting of peridotite from 1 to $100 \%$ and from 40 to $100 \mathrm{kbar}$, and the results are compared to the geochemistry of komatiites. This information is used to address the depths and degrees of melting, and the thermal state of the Earth during their formation.

These problems gain special significance now because komatiites have the potential of being probes into the major element geochemical structure of the mantle. If, for example, the Munro-type komatiites formed by melting in excess of $50 \%$, melting itself would have had to commence at lower mantle pressures ( $>200 \mathrm{kbar}$ [Miller et al., 1991b]), indicating a peridotite source region distributed throughout portions of the lower mantle during Archean times. Similarly, if the Barberton komatiites were formed by extensive melting, the source region must have been very different from mantle peridotite, possibly similar to piclogite in the transition zone [Anderson, 1989]. It is demonstrated in this paper that this kind of information cannot be obtained because the geochemistry of komatiites is determined largely by phase equilibrium processes rather than by the bulk composition of their source region.

\section{EXPERIMENTAL METHOD AND RESUlts}

With one exception, all experiments were carried out using the 2000-ton split sphere anvil apparatus at Stony Brook. A detailed description of the press, the sample assembly, and the techniques has been given in numerous papers [Gasparik, 1989, 1990; Herzberg et al., 1990; Herzberg and Gasparik, 1991], and will not be repeated here.

The starting materials were naturally occurring komatiites and several compositions in $\mathrm{CaO}-\mathrm{MgO}-\mathrm{Al}_{2} \mathrm{O}_{3}-\mathrm{SiO}_{2}$ (CMAS), and they are listed in Table 1 . The compositions and experiments in CMAS are identical to the ones reported by Herzberg and Gasparik [1991]. In both this and the companion study, melting 
TABLE 1. Compositions of Starting Materials and Average Mantle Peridotite

\begin{tabular}{|c|c|c|c|c|c|c|}
\hline & $\stackrel{1}{\mathrm{C}_{67} \mathrm{PX}_{33}}$ & $\begin{array}{c}2 \\
\mathrm{C}_{30} \mathrm{PX}_{30}\end{array}$ & $\begin{array}{l}3 \\
\mathbf{P X}\end{array}$ & $\begin{array}{c}4 \\
\text { HSS-15 }\end{array}$ & $\begin{array}{c}5 \\
P 9-118\end{array}$ & $\begin{array}{c}6 \\
\text { Mantle }\end{array}$ \\
\hline $\mathrm{SiO}_{2}$ & 53.14 & 54.58 & 58.92 & 46.77 & 44.26 & 44.47 \\
\hline $\mathrm{TiO}_{2}$ & - & - & - & 0.33 & 0.35 & 0.10 \\
\hline $\mathrm{Al}_{2} \mathrm{O}_{2}$ & 3.37 & 2.53 & - & 3.42 & 7.38 & 2.57 \\
\hline $\mathrm{Fe}_{2} \mathrm{O}_{3}$ & - & - & - & 1.88 & - & - \\
\hline $\mathbf{F e O}$ & - & - & - & 9.38 & 13.26 & 8.31 \\
\hline $\mathrm{MnO}$ & - & - & - & 0.19 & 0.26 & 0.13 \\
\hline $\mathrm{MgO}$ & 39.12 & 38.23 & 35.58 & 31.51 & 27.37 & 40.98 \\
\hline $\mathrm{CaO}$ & 4.37 & 4.66 & 5.50 & 5.67 & 6.31 & 2.46 \\
\hline $\mathrm{Na}_{2} \mathrm{O}$ & - & - & - & 0.12 & 0.06 & 0.23 \\
\hline $\mathrm{K}_{2} \mathrm{O}$ & - & - & - & 0.08 & 0.08 & 0.05 \\
\hline $\mathrm{Cr}_{2} \mathrm{O}_{3}$ & - & - & - & 0.34 & 0.48 & 0.43 \\
\hline $\mathrm{NiO}$ & - & - & - & 0.27 & 0.20 & 0.27 \\
\hline Total & 100.00 & 100.00 & 100.00 & 99.96 & 100.00 & 100.00 \\
\hline $\mathrm{CaO} /\left(\mathrm{CaO}+\mathrm{Al}_{2} \mathrm{O}_{3}\right)$ & 0.56 & 0.65 & 1.00 & 0.62 & 0.46 & 0.49 \\
\hline
\end{tabular}

TABLE 2. Experimental Results

\begin{tabular}{|c|c|c|c|c|}
\hline $\begin{array}{l}\text { Starting } \\
\text { Material }\end{array}$ & $\begin{array}{l}T \text { Nominal } \\
{ }^{\circ} \mathrm{C}\end{array}$ & $\underset{\text { kbar }}{P}$ & $\begin{array}{c}\text { Time } \\
\min \end{array}$ & $\begin{array}{l}\text { Crystallization } \\
\text { Sequence }\end{array}$ \\
\hline 1 & 2000 & 80 & 4.0 & $\mathrm{~L}, \mathrm{Opx}, \mathrm{Ol}, \mathrm{Gt}, \mathrm{Cpx}[\mathrm{Ol}+\mathrm{Cpx}+\mathrm{Opx}+\mathrm{Gt}]$ \\
\hline 1 & 2050 & 90 & 4.0 & $\mathrm{~L}, \mathrm{Opx}, \mathrm{Ol}, \mathrm{Gt}, \mathrm{Cpx}[\mathrm{OI}+\mathrm{Cpx}+\mathrm{Opx}+\mathrm{Gt}]$ \\
\hline 1 & 2070 & 100 & 3.0 & $\mathrm{~L}, \mathrm{Opx}, \mathrm{Ol}, \mathrm{Gt}, \mathrm{Cpx}[\mathrm{Ol}+\mathrm{Cpx}+\mathrm{Opx}+\mathrm{Gt}]$ \\
\hline 1 & 2140 & 110 & 4.0 & $\mathrm{~L}, \mathrm{Opx}, \mathrm{Ol}+\mathrm{Gt}, \mathrm{Cpx}[\mathrm{Ol}+\mathrm{Cpx}+\mathrm{Opx}+\mathrm{Gt}]$ \\
\hline 2 & 2080 & 100 & 4.0 & $\mathrm{~L}, \mathrm{Opx}, \mathrm{Ol}, \mathrm{Gt}+\mathrm{Cpx}[\mathrm{OI}+\mathrm{Cpx}+\mathrm{Opx}+\mathrm{Gt}]$ \\
\hline 2 & 2140 & 110 & 2.0 & $\mathrm{~L}, \mathrm{Opx}, \mathrm{Ol}, \mathrm{Gt}, \mathrm{Cpx}[\mathrm{Ol}+\mathrm{Cpx}+\mathrm{Opx}+\mathrm{Gt}]$ \\
\hline 2 & 2220 & 130 & 5.0 & $\mathrm{~L}, \mathrm{Gt}, \mathrm{Cp}_{\mathrm{p} 2}, \mathrm{Cp}_{\mathrm{p} 1}, \mathrm{O1^{* }}\left[\mathrm{Ol}+\mathrm{Cp}_{\mathrm{p} \times 1}+\mathrm{Cp}_{\mathrm{p} 2}+\mathrm{Gt}\right]$ \\
\hline 2 & 2240 & 140 & 4.0 & $\mathrm{~L}, \mathrm{Gt}, \mathrm{Cpx} 2, \mathrm{Cpx1}, \mathrm{Ol}[\mathrm{Ol}+\mathrm{Cpx} 1+\mathrm{Cpx} 2+\mathrm{Gt}]$ \\
\hline 3 & 2200 & 150 & 4.0 & $\mathrm{~L}, \mathrm{Cpx}_{\mathrm{2}}, \mathrm{Cpx} 1[\mathrm{Cpx1}+\mathrm{Cp \times 2}]$ \\
\hline 3 & 2240 & 160 & 4.0 & $\mathrm{~L}, \mathrm{Gt}, \mathrm{Cpxi}[\mathrm{Gt}]$ \\
\hline 4 & 1920 & 80 & 4.0 & $\mathrm{~L}, \mathrm{Opx}, \mathrm{Ol}, \mathrm{Cpx}, \mathrm{Gt}[\mathrm{Ol}+\mathrm{Cpx}+\mathrm{Gt}]$ \\
\hline 4 & 1920 & 100 & 5.0 & $\mathrm{~L}, \mathrm{Opx}, \mathrm{Gt}, \mathrm{Ol}, \mathrm{Cpx}[\mathrm{Ol}+\mathrm{Cpx}+\mathrm{Gt}]$ \\
\hline 5 & 1600 & 29 & 60.0 & $\mathrm{~L}, \mathrm{Ol}, \mathrm{Cpx}, \mathrm{Opx},\{\mathrm{Gt}\}[?]$ \\
\hline
\end{tabular}

[Phases in square brackets] $=$ subsolidus phase assemblage. $\{G t\}=$ Garnet inferred, not observed.

Cpx1 = High $\mathrm{Ca}$ Clinopyroxene.

* Opx transforms to Cpx2, a low Ca clinopyroxene, between 110 and 120 kbar [Herzberg and Gasparik, 1991].

experiments were performed on compositions that contain on the solidus the phase assemblage Liquid + Olivine + Orthopyroxene + Clinopyroxene + Garnet $(\mathrm{L}+\mathrm{Ol}+\mathrm{Opx}+$ $\mathrm{Cpx}+\mathrm{Gt})$ in the $80-$ to $160-\mathrm{kbar}$ range. The purpose of the Herzberg and Gasparik [1991] study was to calibrate the compositions of coexisting garnets and pyroxenes that occur at all conditions in the upper mantle and transition zone. The starting material compositions were carefully selected in order to provide excess orthopyroxene at all conditions, and to provide the greatest probability of observing liquids that were multiply saturated in the greatest number of crystalline phases. In addition to highly precise equilibrium pyroxene and garnet compositions, these experimental data provide improved constraints on the compositions of the liquids for the solidus assemblage $\mathrm{L}+\mathrm{Ol}+\mathrm{Opx}+\mathrm{Cpx}+\mathrm{Gt}$. The purpose of this paper is to present these liquid data in light of the komatiite problem.

Starting materials were loaded into rhenium containers, and $10 \mathrm{~mm}$ size assemblies were used. These were then fired at $1000^{\circ} \mathrm{C}$ for 1 hour prior to running in order to expell all water. Run conditions ranged from 80 to $160 \mathrm{kbar}$, and from 2000 to $2240^{\circ} \mathrm{C}$ nominal. Run durations were typically 3 to $5 \mathrm{~min}$. Thin sections were made of the run products, and the garnet and pyroxene compositions were determined by electron probe analysis [Herzberg and Gasparik, 1991].

Of particular interest here is the crystallization sequence, or the order of the phases as they appear from the hot spot to the cold end. These are listed in Table 2. The nomenclature L, 
Opx, Ol, Gt, Cpx [Opx $+\mathrm{Ol}+\mathrm{Gt}+\mathrm{Cpx}]$ refers to this crystallization sequence, which is a short-hand notation for $L ; L$ $+\mathrm{Opx} ; \mathrm{L}+\mathrm{Opx}+\mathrm{Ol} ; \mathrm{L}+\mathrm{Opx}+\mathrm{Ol}+\mathrm{Gt} ; \mathrm{L}+\mathrm{Opx}+\mathrm{Ol}$ $+\mathrm{Gt}+\mathrm{Cpx}$; the subsolidus phase assemblage is given in brackets $[\mathrm{Opx}+\mathrm{Ol}+\mathrm{Gt}+\mathrm{Cpx}]$. The nominal temperatures given in Table 2 are temperatures recorded by the thermocouple. The thermocouple junction is located close to but to one side of the hot spot, and the temperature it reads is valid at one point along the temperature gradient. This is $50^{\circ} \mathrm{C}$ within $0.7 \mathrm{~mm}$ of the hot spot, increasing to about $250^{\circ} \mathrm{C}$ to the cold end of the capsule, about $2 \mathrm{~mm}$ distant [Herzberg et al., 1990]. In most experiments the nominal temperature is slightly above the solidus temperature [Herzberg and Gasparik, 1991], and the crystalline phases of interest are usually distributed within $1 \mathrm{~mm}$ of the hot spot where the temperature gradient is minimal. The liquidus and solidus temperatures differ by $100-150^{\circ} \mathrm{C}$, and it is within this temperature range where the crystallization sequence can be observed.

A source of some concern involves the acquisition of phase equilibrium information in a temperature gradient, and again a detailed discussion of this problem appears in Herzberg et al. [1990]. The major effect is the expulsion of some intergranular melt toward the hot spot and solution-precipitation of the crystalline phases, observations that were originally made and discussed by Lesher and Walker [1988] from piston-cylinder experiments. The concern is that this process could affect the liquidus phase and crystallization sequence. For experiments that range from seconds to $10 \mathrm{~min}$., we have observed no changes in the liquidus phase, in agreement with the treatment of Lesher and Walker [1988]. However, for liquids that are multiply saturated in two or more crystalline phases, these phases are not always distributed in the cotectic proportions that would be expected from crystallization in the absence of a temperature gradient. Rather, some phases concentrate in bands that parallel the isotherms for experiments greater than $2-3$ minutes in duration [see Figures 7, 10, \& 19 in Herzberg et al., 1990]. These phases are ordered along the temperature gradient in a way that reflects the crystallization sequence. In experiments containing only three crystalline phases, the liquidus phase is obvious, the second phase appears at and below the solidus, and the third phase is distributed between these two bounding phases. A more complicated case involves four crystalline phases. A good example involves the case of peritectic melting in the $80 \mathrm{kbar}$ experiment on natural komatiite HSS-15 (Table 2). The crystallization sequence is $\mathrm{L}, \mathrm{Opx}, \mathrm{Ol}, \mathrm{Cpx}, \mathrm{Gt},[\mathrm{Ol}+\mathrm{Cpx}+\mathrm{Gt}]$. Orthopyroxene is completely absent in the subsolidus, but is abundant and ubiquitous throughout the crystallization interval. Identical observations were reported by $O^{\prime} H$ Hara and Yoder [1967] on the melting of a mixture of olivine + garnet + clinopyroxene at $\mathbf{3 0}$ kbar by a series of isothermal piston-cylinder experiments, each with a minimal temperature gradient. The melting relation proposed by O'Hara and Yoder [1967] is $\mathrm{L}+\mathrm{Opx}=\mathrm{Ol}+\mathrm{Cpx}$ $+\mathrm{Gt}$, identical to the one reported by us at 50 and $100 \mathrm{kbar}$ [Herzberg et al., 1990](see below) based on observations of the isobaric crystallization sequence and the compositions of coexisting pyroxenes. We have now obtained internally consistent isobaric phase diagrams from experiments done on a wide range of different starting material compositions, and have encountered no complications arising from the temperature gradient.

In two important experiments, a pair of phases were observed to appear simultaneously along an isotherm. These are
$\mathrm{Ol}+\mathrm{Gt}$ at $2140^{\circ} \mathrm{C}$ and $110 \mathrm{kbar}$, and $\mathrm{Gt}+\mathrm{Cpx}$ at $2080^{\circ} \mathrm{C}$ and 100 kbar (Table 2). In the latter experiment, olivine was observed several tens of degrees up the temperature gradient, indicating a close approach to simultaneous crystallization of olivine, clinopyroxene, and garnet for this composition at the solidus. Experiments like these yield the most information on the T-P-X disposition of cotectics and invariant points, and these are discussed below.

A 29 kbar experiment on a natural komatiite is also reported in Table 2. This was done with the piston-cylinder apparatus in 1980 at the Johnson Space Center. The purpose of this and others like it was to determine the partitioning of $\mathrm{Fe}$ and $\mathrm{Mg}$ between olivine and liquid; a full reporting of these low pressure data will be made elsewhere in conjunction with new data in the 100-kbar range. The low pressure experiment is included in this paper because it provides a constraint on the compositions of liquids along the high pressure solidus.

\section{Discussion OF RESUlTS}

\subsection{The System $\mathrm{CaO}-\mathrm{MgO}-\mathrm{Al}_{2} \mathrm{O}_{3}-\mathrm{SiO}_{2}$}

The locations of the cotectics and invariant points are projected in Figures 1-4. These figures are very similar to the ones published previously by Herzberg et al. [1990], differing in that the phase boundaries are much more tightly constrained. In particular, it has been possible to position accurately the important parameter $\mathrm{CaO} /\left(\mathrm{CaO}+\mathrm{Al}_{2} \mathrm{O}_{3}\right)$ for liquids on the solidus $(\mathrm{L}+\mathrm{Ol}+\mathrm{Opx}+\mathrm{Cpx}+\mathrm{Gt})$, and this was done by observing simultaneous crystallization of clinopyroxene + garnet at the solidus.

It was determined previously that the generation of liquids coexisting with the four crystalline phases $\mathrm{Ol}+\mathrm{Opx}+\mathrm{Gt}+$ Cpx at 30 and 40 kbar is peritectic and takes the form $L+O p x$ $=\mathrm{Ol}+\mathrm{Gt}+\mathrm{Cpx}$ [Davis, 1964; Davis and Schairer, 1965; $O$ 'Hara and Yoder, 1967]. This peritectic reaction was also observed at 50 and $100 \mathrm{kbar}$ [Herzberg et al., 1990], and our new results support this earlier work (Figure 1). The extensive solubility of enstatite in clinopyroxene at melting conditions yields a small tetrahedron of $\mathrm{Ol}+\mathrm{Opx}+\mathrm{Cpx}+\mathrm{Gt}$, thereby restricting the stabilization of orthopyroxene-bearingassemblages to compositions that are fairly silica-rich, such as chondrite. Liquids generated by melting at 50 and $100 \mathrm{kbar}$ are located outside this tetrahedron, to the enstatite-poor side of the plane $\mathrm{Ol}$ $+\mathrm{Cpx}+\mathrm{Gt}$. The experiments on natural komatiite HSS-15 at 80 and 100 kbar illustrate the peritectic melting behaviour as well (Table 2; point \#4 in Figure 1).

Figure 2 shows that fractionation of orthopyroxene can yield liquids with lower silica contents by crystallization down the cotectic $\mathrm{L}+\mathrm{Ol}+\mathrm{Gt}+\mathrm{Cpx}$ which degenerates to a thermal minimum. The exact location of this thermal minimum has not yet been determined. However, the evidence presently available indicates that it is more siliceous than mantle peridotite analogues in CMAS, similar to the peritectic points [Herzberg et al., 1990].

Presnall and Gasparik [1990] concluded that the silica contents at these peritectics were still too low, based on the location of their $165 \mathrm{kbar}$ eutectic $\mathrm{L}+$ Fo + Opx on the binary $\mathrm{Mg}_{2} \mathrm{SiO}_{4}-\mathrm{MgSiO}_{3}$ (Figure 2). They argued that the peritectic point located by us is in error because it would require an implausibly strong rotation of the $L+F o+O p x$ cotectic, as indicated also in Figure 2 . But this criticism is actually erroneous because it stems from a distortion in the diopside 


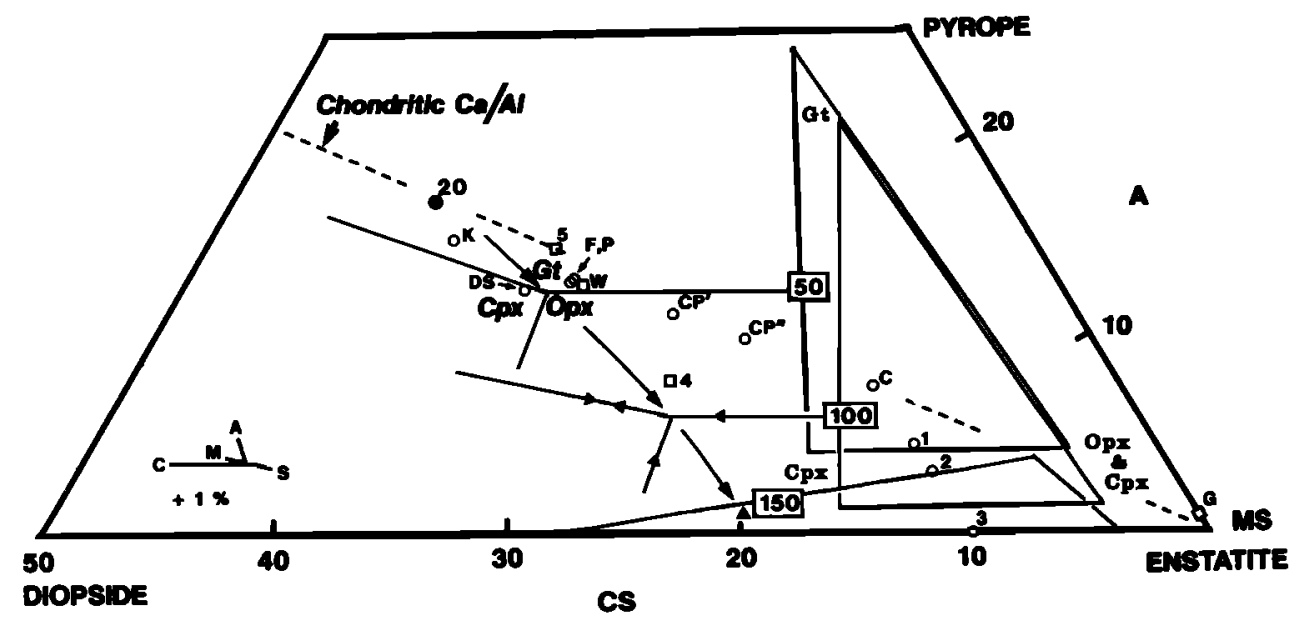

Fig. 1. A projection to and from olivine $\left(M_{2} S\right)$ into part of the plane CS-MS-A (mole percent) [ $O$ 'Hara, 1968], modified after Herzberg et al. [1990]. Gamet and pyroxene compositions at the pressures indicated (kilobars) are from Herzberg and Gasparik [1991]. The crystallization fields and cotectics are strictly valid for the system $\mathrm{CaO}-\mathrm{MgO}-\mathrm{Al}_{2} \mathrm{O}_{3}-\mathrm{SiO}_{2}$. DS is 40 kbar invariant point from Davis and Schraier [1965]; F is 54 kbar invariant point from Fujii et al. [1989]; W is natural komatiite M620 from Wei et al. [1990]. K (komatiite), P (peridotite), C (chondrite), and CP (chondrite-peridotite mixtures) are compositions and experimental results reported in Herzberg et al. [1990]. Compositions 1, 2, 3, 4, and 5 are listed in Table 1.

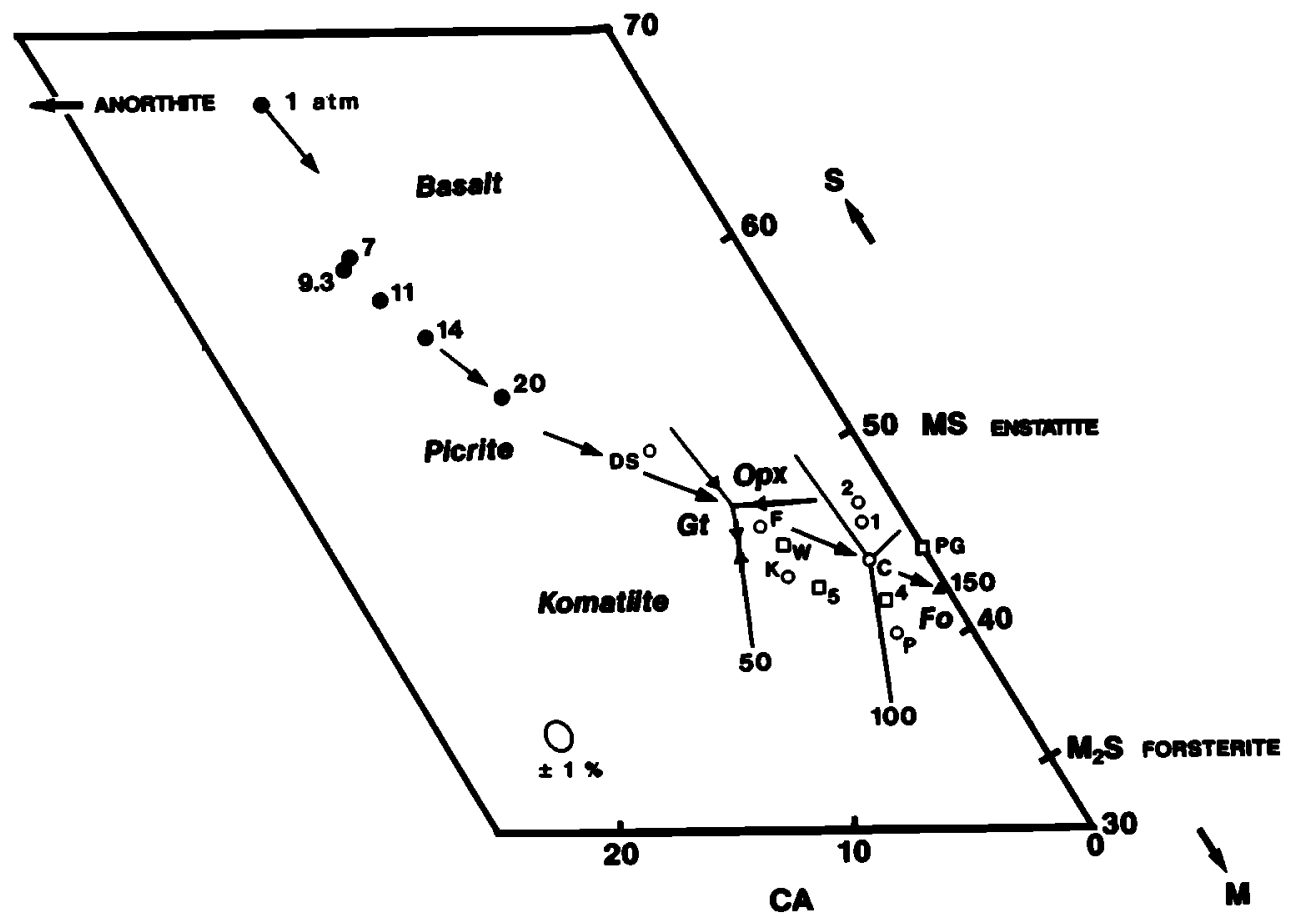

Fig. 2. A projection to and from diopside (CMS) into part of the plane CA-M-S (mole percent) [O'Hara, 1968], modified after Herzberg et al. [1990]. Solid circles are the compositions of liquids formed by isobaric invariant melting on the solidus in $\mathrm{CaO}-$

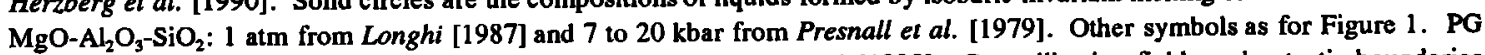
is eutectic in $\mathrm{MgSiO}_{3}-\mathrm{Mg}_{2} \mathrm{SiO}_{4}$ at $165 \mathrm{kbar}$ from Presnall and Gasparik [1990]. Crystallization fields and cotectic boundaries are strictly valid for the system $\mathrm{CaO}-\mathrm{MgO}-\mathrm{Al}_{2} \mathrm{O}_{3}-\mathrm{SiO}_{2}$ (kbar), and may or may not be saturated in clinopyroxene.

projection. This point is illustrated better in Figure 3, a projection from $\mathrm{Al}_{2} \mathrm{O}_{3}$ into a part of the plane $\mathrm{CaO}-\mathrm{MgO}-\mathrm{SiO}_{2}$. It can be seen that pressure does indeed rotate the cotectic $\mathrm{L}+$ Fo + Opx rather substantially, and that the peritectic invariant points at 100 to $150 \mathrm{kbar}$ have contents of silica that are very similar to those on the forsterite-enstatite join.

At $50 \mathrm{kbar}$ the crystallization field of orthopyroxene is very extensive (Figure 1), and orthopyroxene will participate in the melting of mantle peridotite $(\mathrm{L}+\mathrm{Ol}+\mathrm{Opx}+\mathrm{Cpx}+\mathrm{Gt}$; Figure 1) [Herzberg et al., 1990]. Pressure causes the orthopyroxene crystallization field to contract, and at $100 \mathrm{kbar}$ it is absent for mantle peridotite which will melt to the assemblage $\mathrm{L}+\mathrm{Ol}+\mathrm{Gt}+\mathrm{Cpx}$ on the solidus. Initial melting is strictly pseudoinvariant because the liquid is unlikely to be perfectly coincident in composition with the thermal minimum. These initial liquids and the thermal minimum are probably enriched in $\mathrm{SiO}_{2}$ compared to mantle peridotite (Figure 2), and progressive melting will cause a reduction in these silica contents by migration up the cotectic $\mathrm{L}+\mathrm{Ol}+\mathrm{Gt}+\mathrm{Cpx}$ (Figure 2).

Figure 4 is a projection from enstatite into a plane that contains forsterite - diopside - pyrope. It is geologically very useful because the compositions of most mantle peridotites and 
komatiites are contained close to this plane, so that ambiguities stemming from distortions are minimized. The advantage of viewing things this way is that we can now concentrate on the contents of $\mathrm{CaO}$ and $\mathrm{Al}_{2} \mathrm{O}_{3}$, and how these change with pressure. The most important observation is that pressure greatly expands the crystallization field of garnet at the expense of both olivine and clinopyroxene (Figure 4), and garnet can be seen to expand at the expense of orthopyroxene as well (Figure 1). This causes a very pronounced increase to occur in $\mathrm{CaO} /\left(\mathrm{CaO}+\mathrm{Al}_{2} \mathrm{O}_{3}\right)$ for liquids that are multiply saturated in $\mathrm{Cpx}+\mathrm{Gt}$, and this is shown in Figure 5.

The experimental data in CMAS position $\mathrm{CaO} /(\mathrm{CaO}+$ $\mathrm{Al}_{2} \mathrm{O}_{3}$ ) at 0.65 and $100 \mathrm{kbar}$ (Table $2 ; 2080^{\circ} \mathrm{C}$ and $100 \mathrm{kbar}$ ). Near $160 \mathrm{kbar}$, this value increases to 1.0 , based on the stabilization of majorite garnet in the alumina-free system CMS;

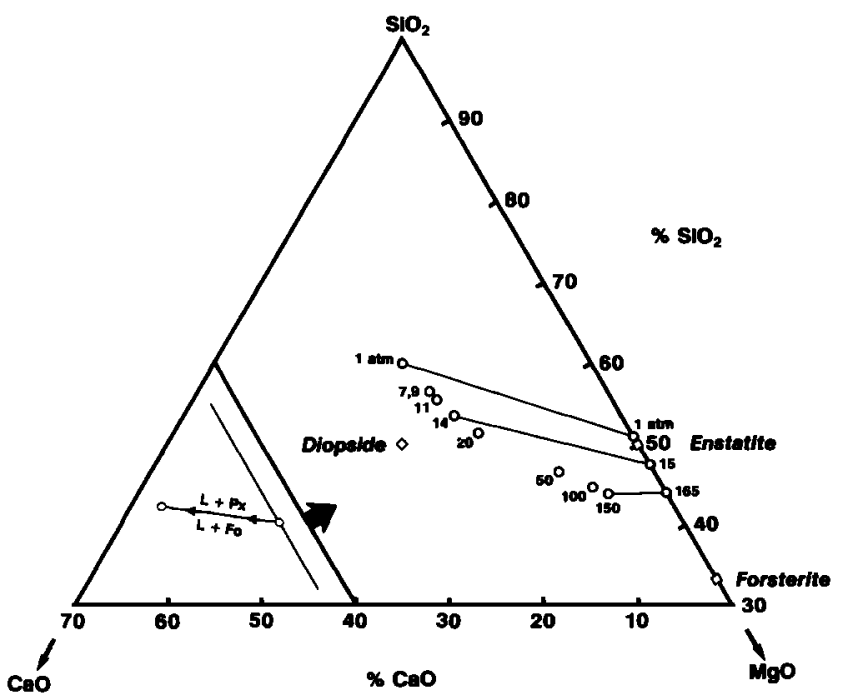

Fig. 3. A projection of invariant points and the cotectic equilibrium $L$ $+\mathrm{Fo}+\mathrm{Px}$ from alumina $\left(\mathrm{Al}_{2} \mathrm{O}_{3}\right)$ into part of the plane $\mathrm{CaO}-\mathrm{MgO}-\mathrm{SiO}_{2}$. Data on the join $\mathrm{MgO}-\mathrm{SiO}_{2}$ : 1 atm from Andersen [1915]; $15 \mathrm{kbar}$ from Taylor [1973]; 165 kbar from Presnall and Gasparik [1990]. a thermodynamic analysis of these results positions it more precisely at $158 \mathrm{kbar}$ [Herzberg and Gasparik, 1991]. At 140 kbar, $\mathrm{CaO} /\left(\mathrm{CaO}+\mathrm{Al}_{2} \mathrm{O}_{3}\right)$ is constrained to be greater than 0.79; this was determined from solidus garnets occurring without clinopyroxene, data reported in Herzberg et al. [1990] together with the equilibrium constant that describes the partitioning of $\mathrm{CaO}$ and $\mathrm{Al}_{2} \mathrm{O}_{3}$ between garnet and liquid [Herzberg and Gasparik, 1991]. Included in Figure 5 are experimental data in natural FeO-bearing systems from many sources. The important observation is that these additional components have no effect, a point discussed in more detail below.

At pressures greater than or equal to $158 \mathrm{kbar}$, pyroxenes cannot crystallize in the melting interval for any composition because of the extensive crystallization field of majorite garnet. Alumina is absent in liquids generated on the solidus (i.e., $\left.\mathrm{CaO} /\left(\mathrm{CaO}+\mathrm{Al}_{2} \mathrm{O}_{3}\right)=1.0\right)$, but it can be present in liquids located between the liquidus and solidus. This condition is likely to persist until about 180 kbar where calcium perovskite has been predicted to become stabilized relative to majorite garnet [Gasparik, 1990]. At pressures greater than this, liquids on the solidus will contain $\mathrm{Al}_{2} \mathrm{O}_{3}$ once again. A better understanding of these very high pressure phase relations must await the acquisition of additional experimental data.

The phase equilibrium data reported here and in Herzberg et al. [1990] for the system CMAS have permitted for the first time estimates of the absolute compositions of the liquids for the equilibrium $\mathrm{L}+\mathrm{Ol}+\mathrm{Opx}+\mathrm{Cpx}+\mathrm{Gt}$ in the 50- to 100-kbar range. They were determined by randomly varying the liquid composition at $\mathbf{5 0}$ and $\mathbf{1 0 0} \mathrm{kbar}$ until the isobaric invariant points were internally consistent with both the high pressure data (Figures 1-4) and the low pressure data of Presnall et al. [1979]. These liquid compositions are listed in Table 3, together with a rough estimate of the $150 \mathrm{kbar}$ liquid. The latter was estimated in part by the value of unity for $\mathrm{CaO} /\left(\mathrm{CaO}+\mathrm{Al}_{2} \mathrm{O}_{3}\right)$ at $158 \mathrm{kbar}$ (Figure 5).

We are now in a position to evaluate the full range of liquid compositions on the solidus to $150 \mathrm{kbar}$, and the results are shown in Figure 6. The experimental data at $1 \mathrm{~atm}$ to 20 kbar [Longhi, 1987; Presnall et al., 1979] provide an important low pressure reference frame for understanding the high pressure

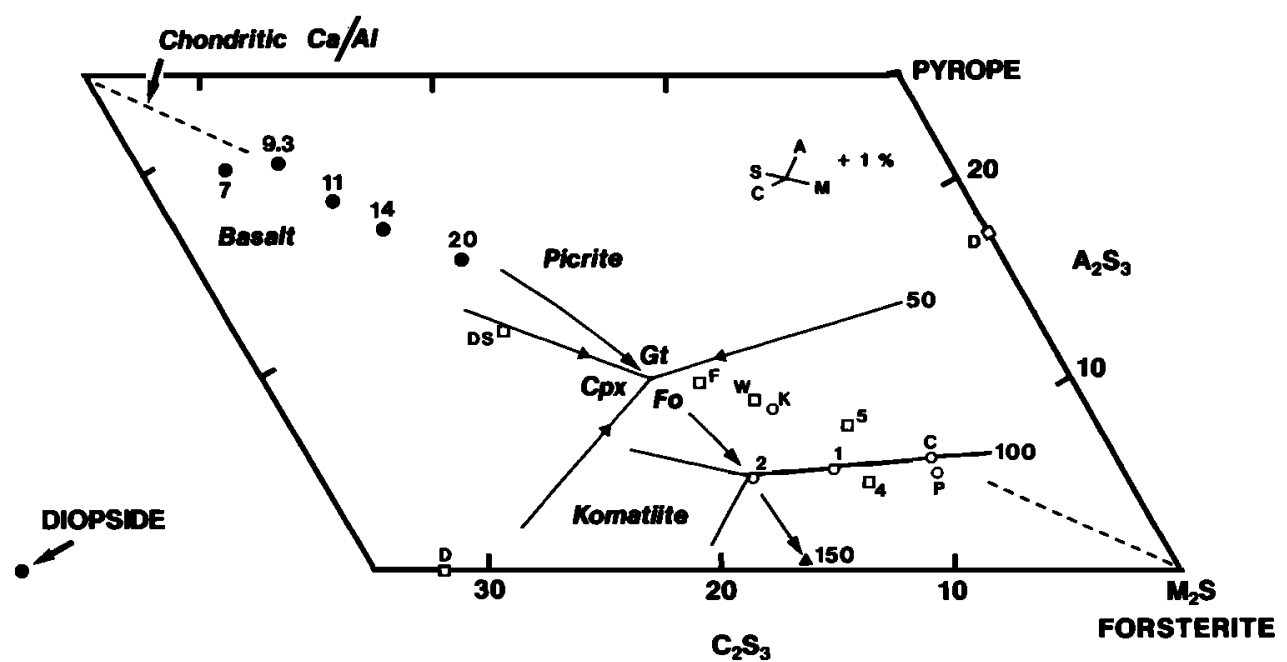

Fig. 4. A projection to and from enstatite (MS) into part of the plane $\mathrm{M}_{2} \mathrm{~S}-\mathrm{C}_{2} \mathrm{~S}_{3}-\mathrm{A}_{2} \mathrm{~S}_{3}$ (mole percent) $\left[\mathrm{O}^{\prime} \mathrm{Hara}, 1968\right]$, modified after Herzberg et al. [1990]. Symbols as for Figures 1 and 2. The crystallization fields and cotectic boundaries are strictly valid for the system $\mathrm{CaO}-\mathrm{MgO}-\mathrm{Al}_{2} \mathrm{O}_{3}-\mathrm{SiO}_{2}$, and may or may not be saturated in orthopyroxene. 
data, and demonstrate that discontinuous changes occur in all oxide components at phase boundaries. These are especially evident at around $9 \mathrm{kbar}$, where plagioclase peridotite transforms to spinel peridotite [Presnall et al., 1979] and at 22 kbar where spinel peridotite transforms to garnet peridotite (Figure 6). The lowest concentrations of $\mathrm{SiO}_{2}$ are 47 to $48 \%$ at $22 \mathrm{kbar}$, and at higher pressures there is a steady increase to about $52 \%$ at 150

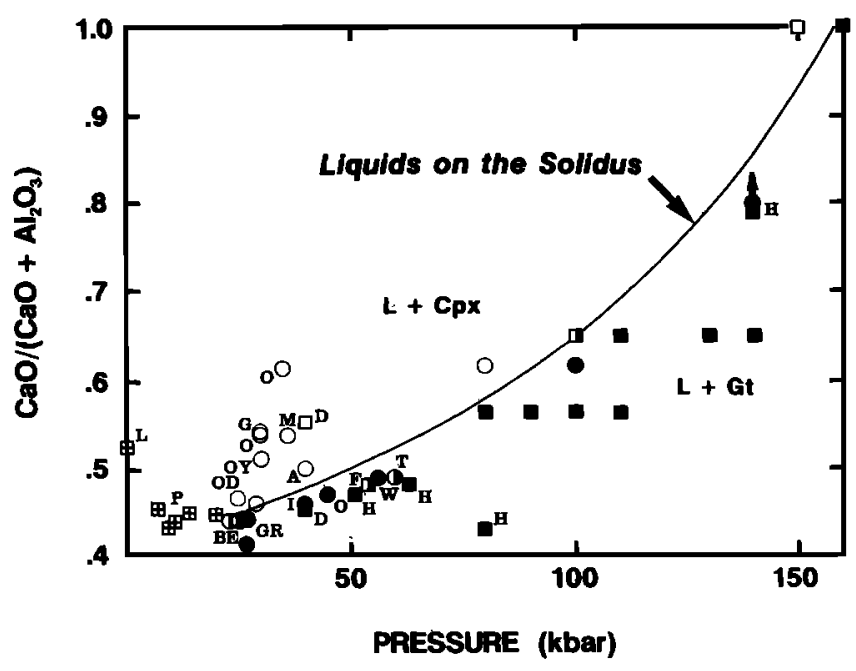

Fig. 5. $\mathrm{CaO} /\left(\mathrm{CaO}+\mathrm{Al}_{2} \mathrm{O}_{3}\right)$ by weight for liquids on the solidus as a function of pressure. Squares are data in $\mathrm{CaO}-\mathrm{MgO}-\mathrm{Al}_{2} \mathrm{O}_{3}-\mathrm{SiO}_{2}$, circles are data in natural $\mathrm{FeO}$-bearing systems. Solid symbols are liquid + garnet; open symbols are liquid + clinopyroxene; half open/half solid symbols are liquid + garnet + clinopyroxene. Squares with crosses are solidus liquids in $\mathrm{CaO}-\mathrm{MgO}-\mathrm{Al}_{2} \mathrm{O}_{3}-\mathrm{SiO}_{2}$ at $1 \mathrm{alm}(\mathrm{L} ;$ Longhi [1987]) and 7 to $20 \mathrm{kbar}$ (P; Presnall et al. [1979]). Unlabelled symbols are data reported in this paper. Other data sources: A, Amdt [1976]; B, Berka and Holloway [1988]; D, Davis [1964]; E, Elthon and Scarfe [1984]; F, Fujii et al. [1989]; G, Falloon et al. [1988]; GR, Green and Ringwood [1967]; H, Herzberg et al. [1990]; I, Ito and Kennedy [1967]; M, Mysen and Kushiro [1976]; O, Howells et al. [1975]; OD, Obata and Dickey [1976]; OY, O'Hara and Yoder [1967]; T, Takahashi [1986]; W, Wei et al. [1990]. The 40 kbar invariant point in CMAS estimated by Davis and Schairer [1965] coincides with data point A. Data of Kushiro et al. [1968] and Takahashi and Kushiro [1983] on peridotite HK66 $\left[\mathrm{CaO} /\left(\mathrm{CaO}+\mathrm{Al}_{2} \mathrm{O}_{3}\right)=0.38\right]$ are anomalous because they show clinopyroxene stable relative to garnet $(\mathrm{L}+\mathrm{Cpx})$ from 30 to $50 \mathrm{kbar}$; this indicates a possible error in their reported bulk composition. kbar. Pressure causes a continuous increase in MgO to contents that are typical of komatiite analogues in CMAS, and it tends to decrease the content of $\mathrm{CaO}$, and most notably $\mathrm{Al}_{2} \mathrm{O}_{3}$, which drops to zero at $158 \mathrm{kbar}$. The low contents of alumina are particularly relevant to the aluminum-depleted komatiites from the Barberton Mountain Land.

The concentrations of these four oxide components at pressures greater than 22 kbar have been fitted to the polynomial:

$\mathrm{SiO}_{2}(\mathrm{wt} \%)=\mathrm{a}+\mathrm{bP}+\mathrm{c} P^{2}+\mathrm{d} P^{3}$

The coefficients $a, b, c$, and $d$ are listed for each oxide component in Table 4. It is important to note that these equations are only valid for liquids that are buffered by the four crystalline phases $\mathrm{Ol}+\mathrm{Opx}+\mathrm{Cpx}+\mathrm{Gt}$. Many naturally-occurring peridotites and peridotite analogues contain orthopyroxene on the solidus at 22 to $50 \mathrm{kbar}$, but loose it at pressures much higher than 80 kilobars. When this occurs, melting is along a cotectic $\mathrm{L}+\mathrm{Ol}+\mathrm{Cpx}+\mathrm{Gt}$ (see above), and the liquids will have contents of $\mathrm{SiO}_{2}$ that are less and contents of $\mathrm{MgO}$ that are somewhat greater than those shown in Figure 6.

\subsection{Natural Complex Systems}

For ultramafic rocks such as komatiites and peridotites, the major difference between the analogue system CMAS and natural complex systems is the presence of iron. The system $\mathrm{CaO}-\mathrm{MgO}-\mathrm{FeO}-\mathrm{Al}_{2} \mathrm{O}_{3}-\mathrm{SiO}_{2}$ (CMFAS) therefore represents about 98-99\% of the geochemistry of these rocks in nature. Several experiments were run on natural komatiite compositions. One is P9-118, an alumina-undepleted komatiite from Munro Township donated to the author by Nicholas Arndt. The other is HSS-15, an alumina-depleted komatiite from the Barberton Mountain Land, originally described by Smith and Erlank [1982]. Melting experiments were reported for HSS-15 by Wei et al. [1990], and samples were donated to the author by Reidar Tronnes. The reason why additional experiments were run on the Barberton sample is because no distinction was reported between clinopyroxene and orthopyroxene in the experiments of Wei et al. [1990]. The distinction is important because it is the observation of multiple saturation in garnet and clinopyroxene that determines the parameter $\mathrm{CaO} /\left(\mathrm{CaO}+\mathrm{Al}_{2} \mathrm{O}_{3}\right)$ for liquids on the solidus. The compositions of these komatiite starting

TABLE 3. Compositions of Liquids on the Anhydrous Solidus

\begin{tabular}{|c|c|c|c|c|c|c|c|c|c|}
\hline \multicolumn{10}{|c|}{ Pressure, kbar } \\
\hline & 1 atm & 7 & 9.3 & 11 & 14 & 20 & 50 & 100 & 150 \\
\hline $\mathrm{SiO}_{2}$ & 55.40 & 50.62 & 49.57 & 49.13 & 48.88 & 48.23 & 49.5 & 51.2 & 52.4 \\
\hline $\mathrm{Al}_{2} \mathrm{O}_{3}$ & 15.20 & 18.95 & 20.54 & 19.72 & 18.45 & 17.47 & 10.0 & 4.2 & 0.5 \\
\hline $\mathrm{MgO}$ & 12.40 & 14.66 & 14.30 & 15.69 & 17.47 & 20.22 & 30.5 & 36.8 & 40.2 \\
\hline $\mathrm{CaO}$ & 17.00 & 15.76 & 15.59 & 15.47 & 15.20 & 14.08 & 10.0 & 7.8 & 6.9 \\
\hline
\end{tabular}

1 atm from Longhi [1987]; 7-20 kbar from Presnall et al. [1979] normalized to 100\%; and 50-150 kbar from this work. 

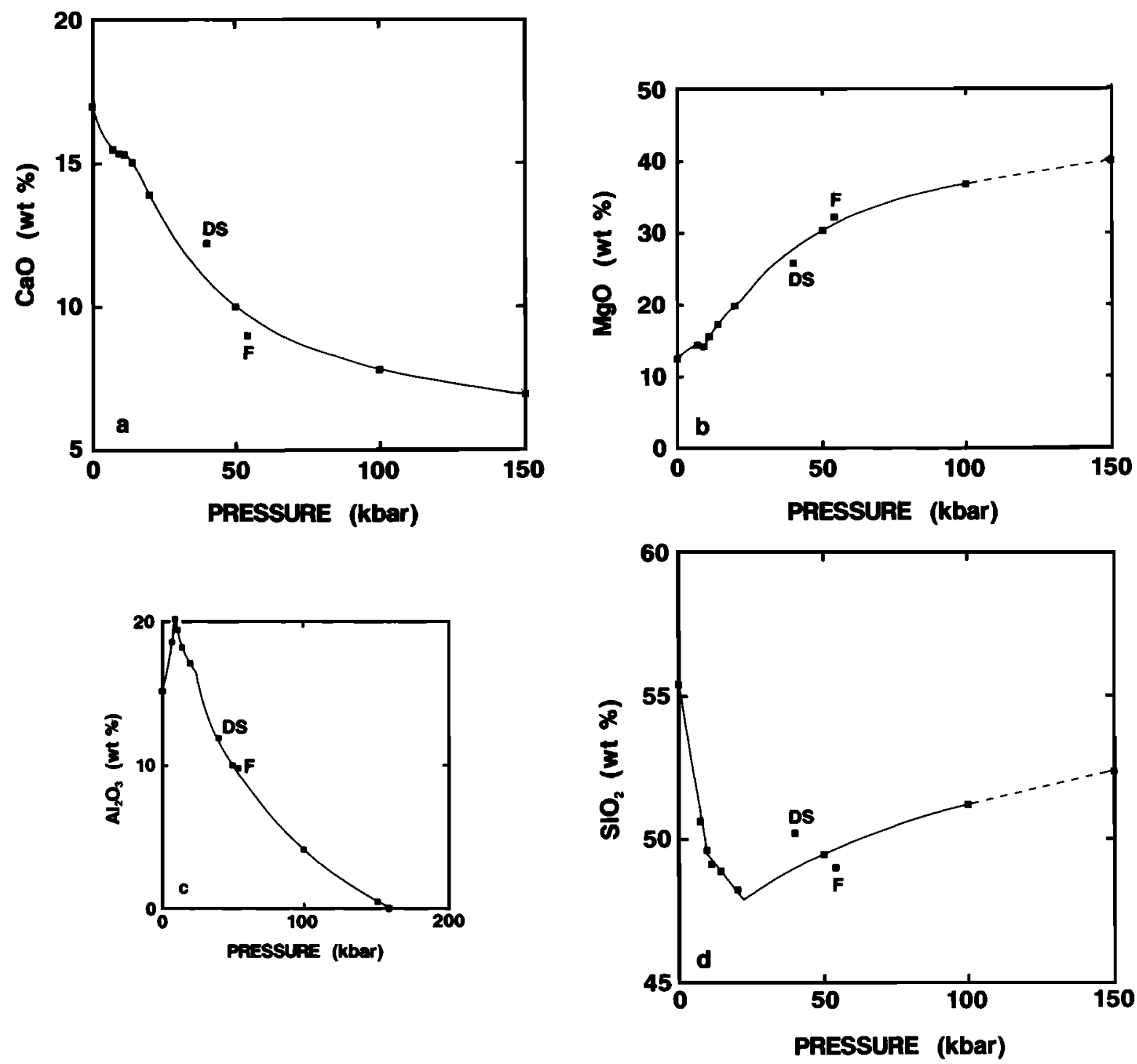

Fig. 6. Compositions of liquids formed on the solidus in the system $\mathrm{CaO}-\mathrm{MgO}-\mathrm{AL}_{2} \mathrm{O}_{3}-\mathrm{SiO}_{2}$. Liquids are for the equilibria: $\mathrm{L}$ + Fo + Opx + Cpx + Anorthite (1 atm to $9.3 \mathrm{kbar}$ [Longhi, 1987; Presnall et al., 1979]); L + Fo + Opx + Cpx + Spinel (9.3 to 22 kbar [Presnall et al., 1979]); L + Ol + Opx + Cpx + Garnel (22 to $158 \mathrm{kbar}$; Table 3). DS, Davis and Schairer [1965]; F, Fujii et al. [1989].

TABLE 4. Coefficients for Liquids on the Anhydrous Solidus in the system $\mathrm{CaO}-\mathrm{MgO}-\mathrm{Al}_{2} \mathrm{O}_{3}-\mathrm{SiO}_{2}$ and at Pressures in the Garnet Stability Field $(\mathrm{L}+\mathrm{Ol}+\mathrm{Opx}+\mathrm{Cpx}+\mathrm{Gt})$

\begin{tabular}{lrrrr}
\hline & a & \multicolumn{1}{c}{ b } & $c\left(10^{-3}\right)$ & $\mathrm{d}\left(10^{6}\right)$ \\
\hline $\mathrm{SiO}_{2}$ & & & & \\
$\mathrm{Al}_{2} \mathrm{O}_{3}$ & 46.15 & 0.0913 & -0.561 & 1.54 \\
$\mathrm{MgO}$ & 26.04 & -0.4775 & 3.677 & -10.86 \\
$\mathrm{CaO}$ & 9.21 & 0.6562 & -5.415 & 16.12 \\
& 18.60 & -0.2699 & 2.299 & -6.80 \\
\hline
\end{tabular}

$\mathrm{SiO}_{2}(\mathrm{wt} \%)=\mathrm{a}+\mathrm{b} P+\mathrm{c} P^{2}+\mathrm{d} P^{3} \ldots$ where $P$ is in kbar

materials are given in Table 1, and the experimental results are included in Table 2.

In the $80 \mathrm{kbar}$ experiment on HSS-15, clinopyroxene occurs above the solidus, and garnet is restricted to temperatures at and below the solidus; the opposite was observed at $100 \mathrm{kbar}$.
These results are shown in Figure 5. The pressure at which multiple saturation occurs in garnet and clinopyroxene is located between these brackets, and is valid for $\mathrm{CaO} /\left(\mathrm{CaO}+\mathrm{Al}_{2} \mathrm{O}_{3}\right)$ of HSS-15, that being 0.62 . This is exactly the vâlue that is predicted by the experimental data in the simple system CMAS.

Most garnet synthesis experiments in natural complex systems have been done on komatiite, peridotite, and eclogite compositions restricted to the 23- to 40-kbar range, and the results are included in Figure 5. The important observation is that the addition of $\mathrm{FeO}$ neither expands nor contracts the crystallization field of garnet with respect to clinopyroxene. This is illustrated by the data of Bertka and Holloway [1988] on a very iron-rich garnet lherzolite composition that is appropriate for Mars. The minimum melt at $23 \mathrm{kbar}$ has the following properties: $23.3 \% \mathrm{FeO} ; 12.7 \% \mathrm{MgO} ; \mathrm{CaO} /\left(\mathrm{CaO}+\mathrm{Al}_{2} \mathrm{O}_{3}\right)=$ 0.44 . In the iron-free system CMAS, it is predicted that $\mathrm{CaO} /\left(\mathrm{CaO}+\mathrm{Al}_{2} \mathrm{O}_{3}\right)=0.44$ at 23 kbar. It can be seen that the parameter $\mathrm{CaO} /\left(\mathrm{CaO}+\mathrm{Al}_{2} \mathrm{O}_{3}\right)$ is common to both CMAS and all geochemical systems of interest. 
Addition of $\mathrm{FeO}$ does not affect the crystallization field of garnet with respect to clinopyroxene presumably because it lowers the freezing temperatures of the iron-free end-members $\mathrm{CaMgSi}_{2} \mathrm{O}_{6}$ and $\mathrm{Mg}_{3} \mathrm{Al}_{2} \mathrm{Si}_{3} \mathrm{O}_{12}$ about equally. The major effect of $\mathrm{FeO}$ is to lower the $\mathrm{SiO}_{2}$ content of a liquid at an isobaric invariant point. In the very $\mathrm{FeO}$-rich composition reported by Bertka and Holloway [1988], $\mathrm{SiO}_{2}=41.9 \%$ for the liquid $(\mathrm{L}$ $+\mathrm{Ol}+\mathrm{Opx}+\mathrm{Cpx}+\mathrm{Gt} ; 23 \mathrm{kbar})$. This compares with about $48 \%$ in the system CMAS (Figure $6 d$ ) and $44.4 \%$ in CMFAS when $\mathrm{MgO}$ is replaced by $\mathrm{FeO}$ in the appropriate proportions. This effect is also observed in other ways. For komatiite HSS15 at 100 kbar (point \#4 in Figures $2 \& 4$ ), the crystallization sequence in CMAS is predicted to be $\mathrm{L}, \mathrm{Opx}, \mathrm{Ol}, \mathrm{Gt}, \mathrm{Cpx}$. This differs from the observed crystallization sequence $\mathrm{L}, \mathrm{Opx}, \mathrm{Gt}, \mathrm{Ol}, \mathrm{Cpx}$, demonstrating that FeO expands the crystallization field of gamet at the expense of olivine. Liquids at isobaric invariant points in CMAS have slightly higher $\mathrm{CaO}$, $\mathrm{Al}_{2} \mathrm{O}_{3}$, and $\mathrm{SiO}_{2}$ than those found in nature. An estimate of these effects is now made.

As a first step in extending CMAS to CMFAS, MgO was replaced by $\mathrm{FeO}$ using the distribution coefficient $K_{D}=$ $(\mathrm{MgO} / \mathrm{FeO})_{\text {Liquid }} \times(\mathrm{FeO} / \mathrm{MgO})_{\text {ohnne. }}$ The value of $K_{D}$ is 0.34 at 30 to $40 \mathrm{kbar}$ [Bickel et al. 1977], and remains fairly constant in the 100-kbar range [Takahashi, 1986; C. Herzberg, unreported data, 1991]. The initial liquid compositions were calculated by mass balance with olivine of a known composition, this being $\mathrm{Fo}_{90}$ for average mantle peridotite [Boyd, 1989], and $\mathrm{Fo}_{75}$ for a presumed Martian mantle olivine [Bertka and Holloway, 1988]. This first step will yield a liquid composition that projects to the same location as that in CMAS. In the second step, the contents of $\mathrm{SiO}_{2}, \mathrm{Al}_{2} \mathrm{O}_{3}$, and $\mathrm{CaO}$ were lowered because $\mathrm{FeO}$ contracts the crystallization field of olivine as discussed above. The Bertka and Holloway [1988] data were used to parameterize this effect, and the results are:

$\mathrm{SiO}_{2}=\left[\mathrm{a}+\mathrm{b} P+\mathrm{c} P^{2}+\mathrm{d} P^{3}\right] \times[1-0.46(\mathrm{FeO} / \mathrm{MgO})]$

where the coefficients $a, b, c$, and $d$ are valid for the system CMAS (Table 4), and $\mathrm{FeO} / \mathrm{MgO}$ (wt.\%) is for the composition of olivine in the source region. Similarly, the reductions in $\mathrm{CaO}$ and $\mathrm{Al}_{2} \mathrm{O}_{3}$ were parameterized by the following:

$$
\begin{aligned}
\mathrm{Al}_{2} \mathrm{O}_{3} & =\left[\mathrm{a}+\mathrm{b} P+\mathrm{c} P^{2}+\mathrm{d} P^{3}\right] \times[1-0.69(\mathrm{FeO} / \mathrm{MgO})] \\
\mathrm{CaO} & =\left[\mathrm{a}+\mathrm{b} P+\mathrm{c} P^{2}+\mathrm{d} P^{3}\right] \times[1-0.69(\mathrm{FeO} / \mathrm{MgO})]
\end{aligned}
$$

The algorithm is simple because CMAS can be extended to CMFAS by the introduction of two constant parameters (i.e., 0.46 and 0.69 ), and two adjustable parameters, the composition of olivine in the source and the degree of partial melting; a copy of it can be obtained from the author as a computer program. Again the liquids so calculated are valid only for initial melting at pressures in the garnet stability field.

Table 5 shows that the calculated iron-rich initial melt composition of Bertka and Holloway is in excellent agreement with the observed composition. The melting of mantle peridotite on Earth at $\mathbf{2 5} \mathrm{kbar}$ will generate picrite, and Table 5 shows that the calculated composition is also in very good agreement with that determined experimentally by Elthon and Scarfe [1984].

Initial liquids formed at 50 kbar contain 23.2 to $25.3 \%$ $\mathrm{MgO}$ and 13.7 to $10.7 \% \mathrm{FeO}$, depending on the degree of partial melting (Table 5). At $100 \mathrm{kbar}, \mathrm{MgO}$ ranges from 27.4 to $30.4 \%$. These compare with $24 \% \mathrm{MgO}$ at $40 \mathrm{kbar}$, determined experimentally by Litvin [1989]. Liquids generated at 50 and $100 \mathrm{kbar}$ invariant points are distinctly komatiitic in composition, and their significance to the Earth will be addressed below. These liquid compositions are now projected in Figures $7 a \& b$ in order to demonstrate the effect of FeO on expanding the crystallization fields of garnet, clinopyroxene, and orthopyroxene at the expense of olivine.

Use of liquid compositions in CMAS are actually very successful when applied to naturally occurring rocks with a terrestrial $\mathrm{FeO} / \mathrm{MgO}$. Simple substitution of $\mathrm{MgO}$ for $\mathrm{FeO}$ without accounting for a contraction of the crystallization field of olivine results in contents of $\mathrm{SiO}_{2}, \mathrm{Al}_{2} \mathrm{O}_{3}$, and $\mathrm{CaO}$ that are too high by $1.7 \%, 0.3 \%$, and $0.6 \%$, respectively (absolute), at $100 \mathrm{kbar} ; \mathrm{MgO}$ and $\mathrm{FeO}$ are too low by $2 \%$ and $0.6 \%$, respectively. However, these small differences can yield very different crystallization sequences. For example, the system CMAS predicts the crystallization sequence $\mathrm{L}, \mathrm{Opx}, \mathrm{Ol}, \mathrm{Gt}, \mathrm{Cpx}$ for HSS-15 at 100 kbar. This compares with L,Opx,Gt,Ol,Cpx, a crystallization sequence that is both experimentally observed (Table 2) and predicted in CMFAS (Figure 7).

At the present time, the largest discrepancy between calculated and observed liquid compositions is for the Elthon and Scarfe [1984] picrite at $25 \mathrm{kbar}$ (Table 5). Although the disagreement is not understood, accepting it at face value illustrates that the calculated and observed liquid compositions differ by no more than the following relative amounts: $+1-5 \%$

TABLE 5. Compositions of Liquids on the Anhydrous Solidus in the System $\mathrm{CaO}-\mathrm{MgO}-\mathrm{FeO}-\mathrm{Al}_{2} \mathrm{O}_{3}-\mathrm{SiO}_{2}$ and at Pressures in the Garnet Stability Field $(\mathrm{L}+\mathrm{Ol}+\mathrm{Opx}+\mathrm{Cpx}+\mathrm{Gt})$

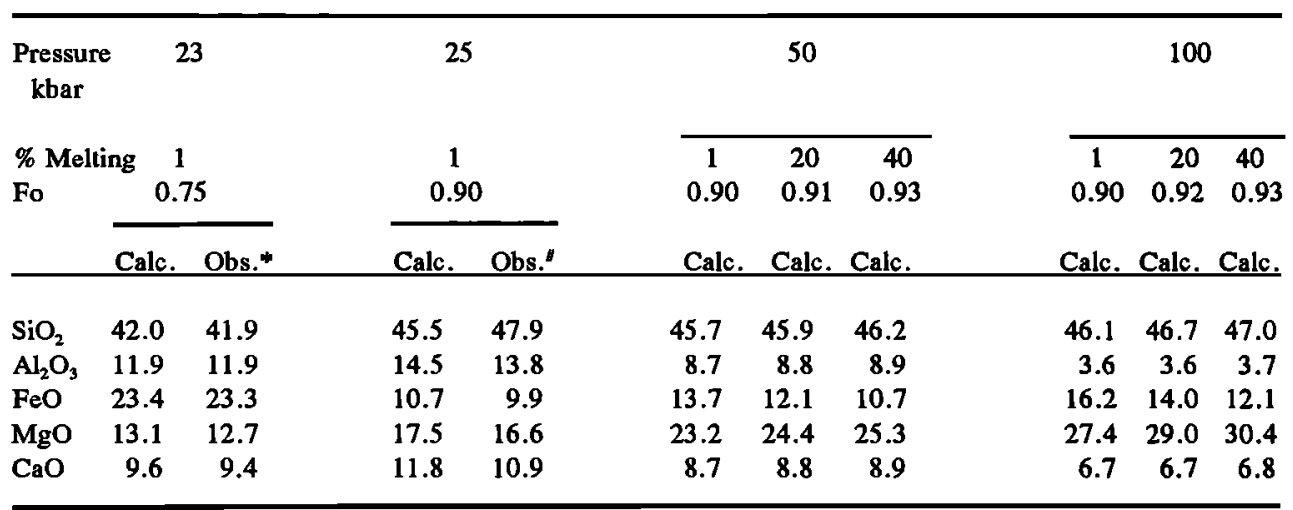

* From Bertka and Holloway [1988].

"From Elthon and Scarfe [1984]. 


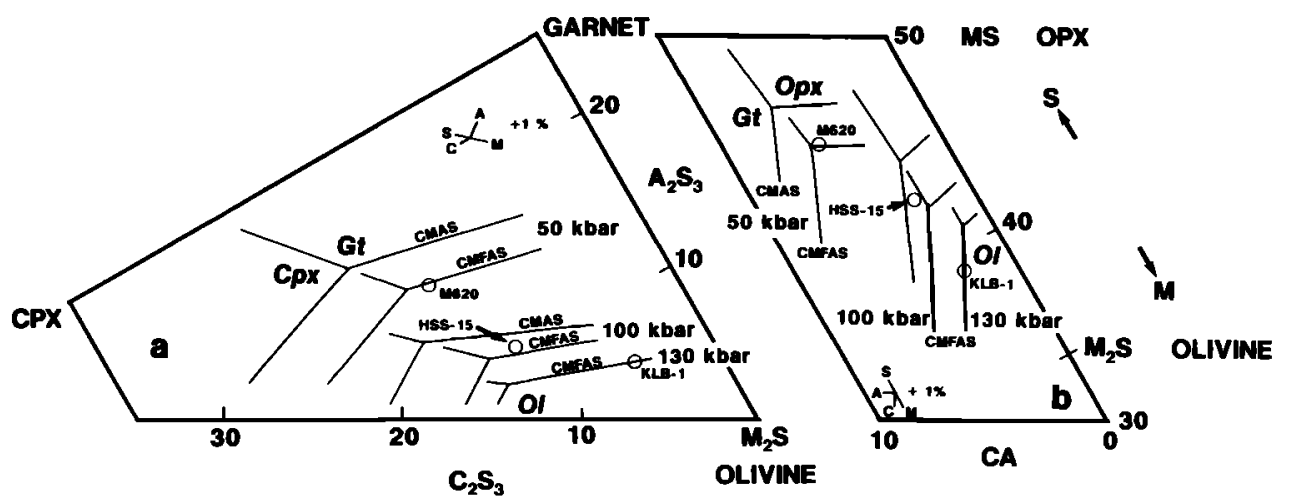

Fig. 7. Pseudoinvariant points and cotectic boundaries in the system CMFAS compared to CMAS (Figures 2 and 4). Experimental work on KLB-1 [Herzberg el al., 1990] show the crystallization sequence L,Gt,Ol,Cpx at 140 kbar; multiple saturation in olivine + garnet $(\mathrm{L}+\mathrm{Ol}+\mathrm{Gl})$ has not been determined, but will not be much lower than $130 \mathrm{kbar}$.

for $\mathrm{SiO}_{2}, \mathrm{Al}_{2} \mathrm{O}_{3}$, and $\mathrm{MgO} ;+/-8 \%$ for $\mathrm{FeO}$ and $\mathrm{CaO}$ (Table 5). The most serious difficulty is with $\mathrm{SiO}_{2}$. The value offered by Elthon and Scarfe [1984] is $47.9 \%$ substantially higher than the calculated value $(45.5 \%)$. But this high $\mathrm{SiO}_{2}$ is probably incorrect because it predicts a crystallization field of olivine $(\mathrm{L}$ $+\mathrm{Ol})$ at 27 to $30 \mathrm{kbar}$ for which orthopyroxene ( + Opx) was observed instead for the binary diopside-pyrope in CMAS, the FeO-bearing composition $\mathrm{Cpx}_{25} \mathrm{Opx}_{25} \mathrm{Gr}_{50}$ (A3/10596) [O'Hara and Yoder, 1967], and the picrite of Green and Ringwood [1967]. Mysen and Kushiro [1977] also reported very low silica contents at $20 \mathrm{kbar}$. It is concluded, therefore, that initial melting in the 25 kbar range yields picritic liquids ( $-16-17 \%$ $\mathrm{MgO}$ ) with low $\mathrm{SiO}_{2}$ (45 - $46 \%$; Table 5).

The component $\mathrm{Na}_{2} \mathrm{O}$ will reduce the amount of $\mathrm{MgO}$ that is contained in liquids on the solidus because it reduces the solubility of olivine in silicate liquids [Herzberg, 1979]. At 15 $\mathrm{kbar}$, the addition of $3.5 \% \mathrm{Na}_{2} \mathrm{O}$ to the system CMAS can reduce $\mathrm{MgO}$ from about $17 \%$ to $10 \%$, and it also contributes to a lowering of $\mathrm{SiO}_{2}$ [D.C.Presnall, personal communication 1991]. This will cause an important uncertainty in estimating the $\mathrm{MgO}$ content of initial liquids in which $\mathrm{Na}_{2} \mathrm{O}$ is concentrated, a problem that is likely to be important for small melt fractions (i.e., 1-2 \%). However, this problem is not likely to be important in interpreting most komatiites because they typically contain less $0.5 \% \mathrm{Na}_{2} \mathrm{O}$, and most of them were formed by degrees of melting that exceeded $25 \%$ (see below). But the reader should be cautioned that liquids on the solidus in the system CMFAS (Table 5) will be too high in $\mathrm{MgO}$, especially for low melt fractions that contain several percent $\mathrm{Na}_{2} \mathrm{O}$.

\section{Depth And Degree Of Melting Of Komatites}

\subsection{Geochemical Types of Komatiites}

In Figure 8 are projected the compositions of 668 peridotites from our world data base [Herzberg et al., 1988, 1990] together with 255 komatiites. The komatiite data base is from too many sources to list, but a sampling includes Nesbitt and Sun [1976], Nesbitt et al. [1979], Arndt et al. [1977], Viljoen and Viljoen [1969], Smith and Erlank [1982], Pyke et al. [1973], and Nisbet et al. [1987]. The peridotites are the socalled "oceanic" types [Boyd, 1989]; these include all samples with the exception of the "continental" types which are the coarse-grained and low temperature xenoliths from sourthern Africa. The average of the 668 peridotites is listed in Table 1, and is very close to the average of 384 spinel lherzolites compiled by Maaloe and Aoki [1977].

The komatiites are divided into two populations. One is the alumina-depleted type komatiite [Nesbitt et al., 1979] which is characteristic of the Barberton Mountain Land and Pilbara, and are these have ages of about $3.5 \mathrm{Ga}$ [Jahn et al., 1982; Gruau et al., 1990a]. The second is the alumina-undepleted type which is most commonly found in other cratons and is typically younger (e.g., $2.7 \mathrm{Ga}$ [Gruau et al., 1990a]); these are well represented by komatiites from the Munro Township in the Abitibi greenstone belt in Canada [Arndt et al., 1977]. The alumina-undepleted character of the Munro komatiites is revealed by their ratio of $\mathrm{CaO} /\left(\mathrm{CaO}+\mathrm{Al}_{2} \mathrm{O}_{3}\right)$ (by weight) that averages 0.49 (see appendix; $\mathrm{CaO} / \mathrm{Al}_{2} \mathrm{O}_{3}=0.99$ ), essentially identical to average mantle peridotite [Herzberg et al., 1990]. The contents of $\mathrm{CaO}$ and $\mathrm{Al}_{2} \mathrm{O}_{3}$ are indicated in Figure 8 by the coordinates $\mathrm{C}_{2} \mathrm{~S}_{3}$ and $\mathrm{A}_{2} \mathrm{~S}_{3}$, the chondritic value included for reference. The alumina-depleted character of the Barberton komatiites is manifest by high $\mathrm{CaO} /\left(\mathrm{CaO}+\mathrm{Al}_{2} \mathrm{O}_{3}\right)$, and this is clearly evident in Figure $8 b$.

Komatiites from the Gorgona Islands have a major element geochemistry that is similar to Munro [Gansser et al., 1979; Echeverria, 1982; Aitken and Echeverria, 1984], and they are important because of they are Mesozoic in age [Walker et al., 1991]. In detail, however, they are slightly lower in both $\mathrm{CaO} /\left(\mathrm{CaO}+\mathrm{Al}_{2} \mathrm{O}_{3}\right)$ and $\mathrm{MgO}$ compared to Munro-type komatiites.

An analysis now follows of the depths and degrees of partial melting that were involved in the formation of the Munrotype, Barberton, and Gorgona komatiites. The depths of melting have been estimated from $\mathrm{CaO} /\left(\mathrm{CaO}+\mathrm{Al}_{2} \mathrm{O}_{3}\right)$. The degrees of partial melting have been estimated by mass balancing the compositions of the liquid and crystalline phases with the bulk composition being melted, so that melting is strictly equilibrium. The compositions of garnet, clinopyroxene, and orthopyroxene at all temperatures and pressures of interest are now very well known, particularly along the solidus, and the compositions used in this analysis have been retrieved from the equations of Herzberg and Gasparik [1991]. The compositions of the liquids on the solidus depend on both pressure and the degree of partial melting, and these were computed for the system CMFAS. For advanced levels of melting (e.g., $\mathrm{L}+\mathrm{Ol}$ and $\mathrm{L}+\mathrm{Ol}+\mathrm{Opx}$ ), the compositions of the liquids were estimated from the disposition of the cotectics, and these are shown in Figures $9 a$, 


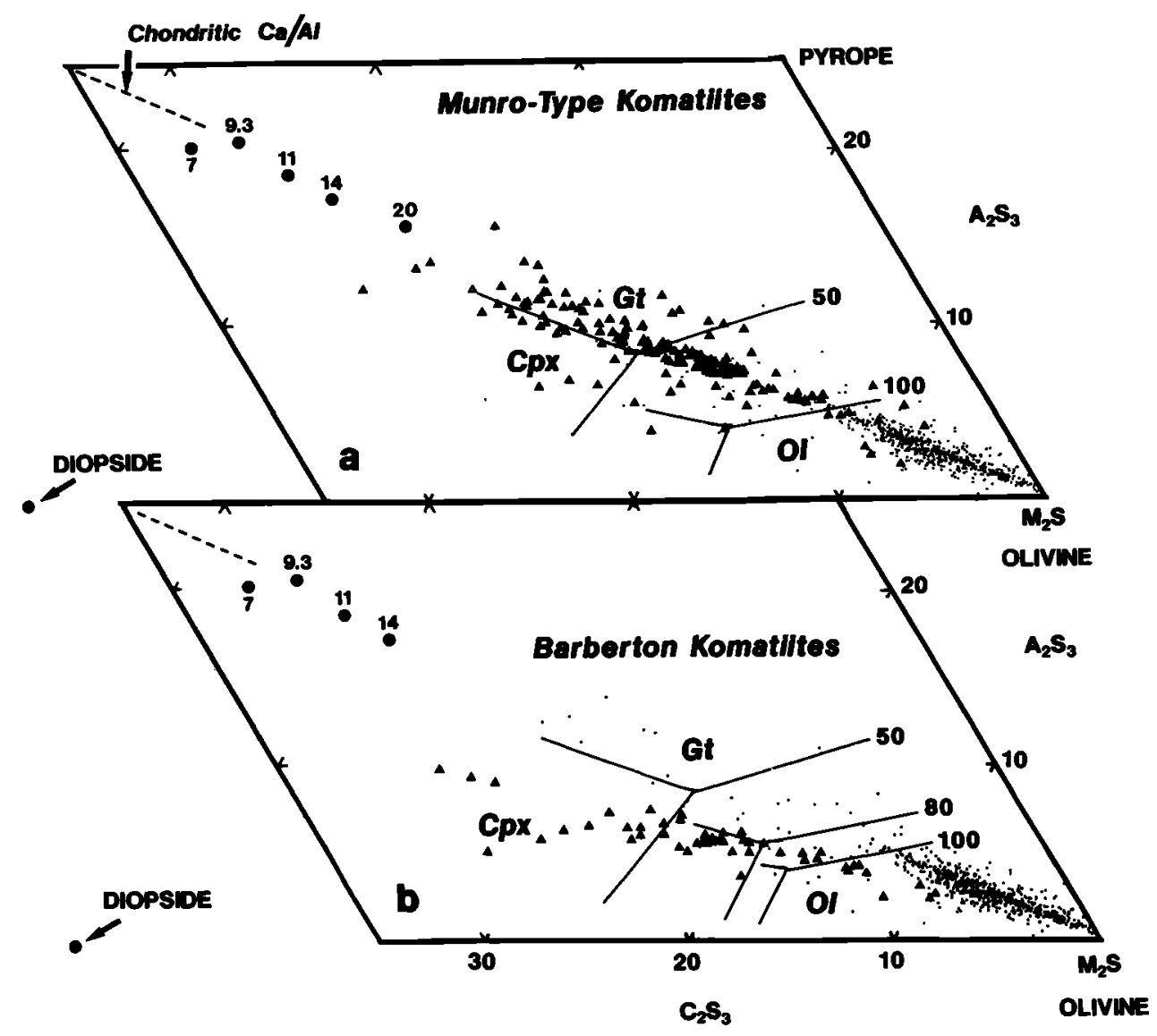

Fig. 8. A projection of liquidus phase boundaries in CMFAS from Figure 7, mantle peridotite (dots), and komatiites (triangles).
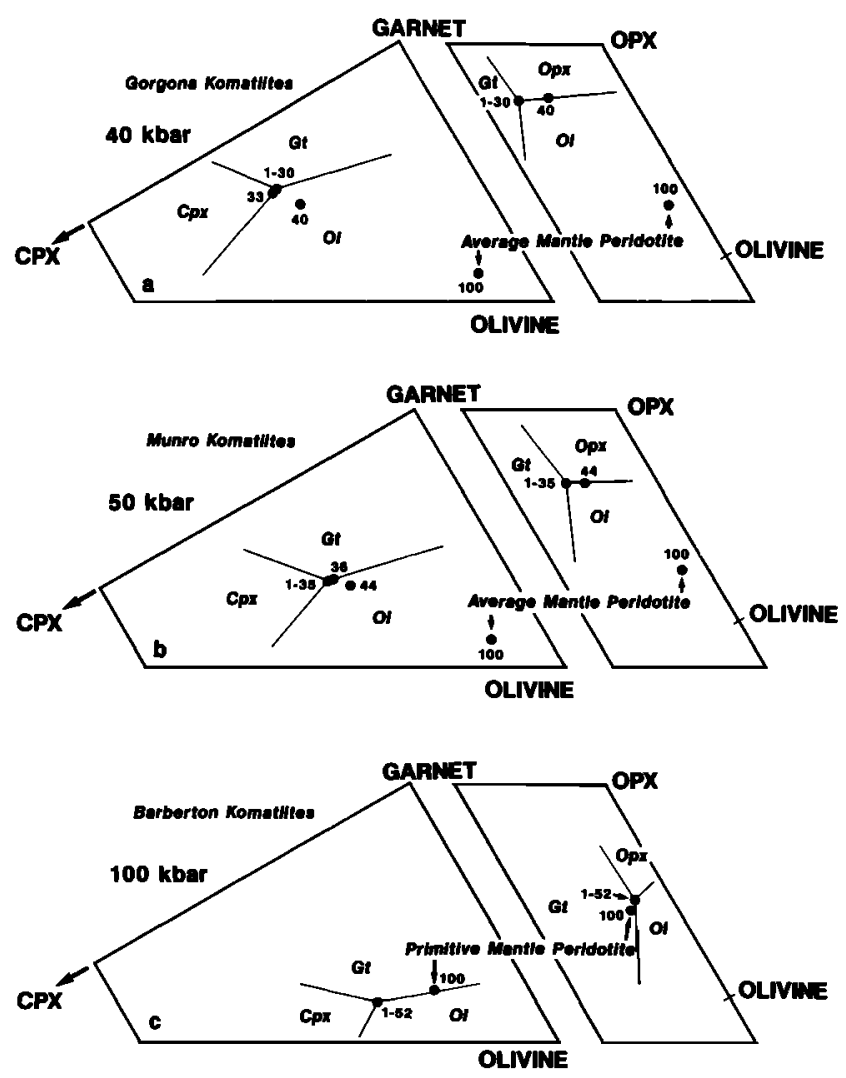

Fig. 9. A projection of liquids formed by the melt percentages shown at (a) 40, (b) 50, and (c) $100 \mathrm{kbar}$. Average mantle peridotite is given in Table 1. Primitive mantle peridotite is Ib8 of Stosch and Seck [1980].
$9 b$, and $9 c$ for the Gorgona, Munro-type, and Barberton komatiites respectively.

\subsection{Gorgona Komatiites}

The parameter $\mathrm{CaO} /\left(\mathrm{CaO}+\mathrm{Al}_{2} \mathrm{O}_{3}\right)$ is restricted to 0.46 0.47 [Echeverria, 1982; Aitken and Echeverria, 1984], indicating a pressure of melting of about $36 \mathrm{kbar}$. There is some indication that $\mathrm{CaO}$ has been removed because of alteration (see below and appendix), so the pressure of melting was probably somewhat higher.

At $40 \mathrm{kbar}$, the partial melting of average mantle peridotite on the solidus will involve the assemblage $\mathrm{L}+\mathrm{Ol}+\mathrm{Opx}+$ $\mathrm{Cpx}+\mathrm{Gt}$, and the degree of melting will range from about 1 to $30 \%$. In CMFAS the liquids formed will have 20 to $23 \%$ $\mathrm{MgO}$ and a low content of $\mathrm{SiO}_{2}$ (i.e., $45-46 \%$ ). The Gorgona komatiites are relatively high in $\mathrm{Na}_{2} \mathrm{O}$ (i.e., about $0.8 \%$ [Aitken and Echeverria, 1984]), indicating that these $\mathrm{MgO}$ contents are overestimated by 1 to $2 \%$ (see above). Nevertheless, the Gorgona komatiites are very similar to these primary liquid compositions, except that they have been modified by addition and subtraction of olivine (Figure 10).

When the degree of partial melting exceeds $30 \%$, garnet is the first phase to be consumed $(\mathrm{L}+\mathrm{Ol}+\mathrm{Opx}+\mathrm{Cpx}) . \mathrm{CaO}$ and $\mathrm{Al}_{2} \mathrm{O}_{3}$ will change slightly until the degree of partial melting reaches $33 \%$, at which point $\mathrm{CaO} /\left(\mathrm{CaO}+\mathrm{Al}_{2} \mathrm{O}_{3}\right)$ of the liquid is 0.49 , defined by the peridotite source. Progressive melting will exhaust clinopyroxene and melting will proceed up the harzburgite cotectic $\mathrm{L}+\mathrm{Ol}+\mathrm{Opx}$. Orthopyroxene will remain in the residue until the degree of melting reaches $40 \%$. It is during the progressive melting of harzburgite where the largest 

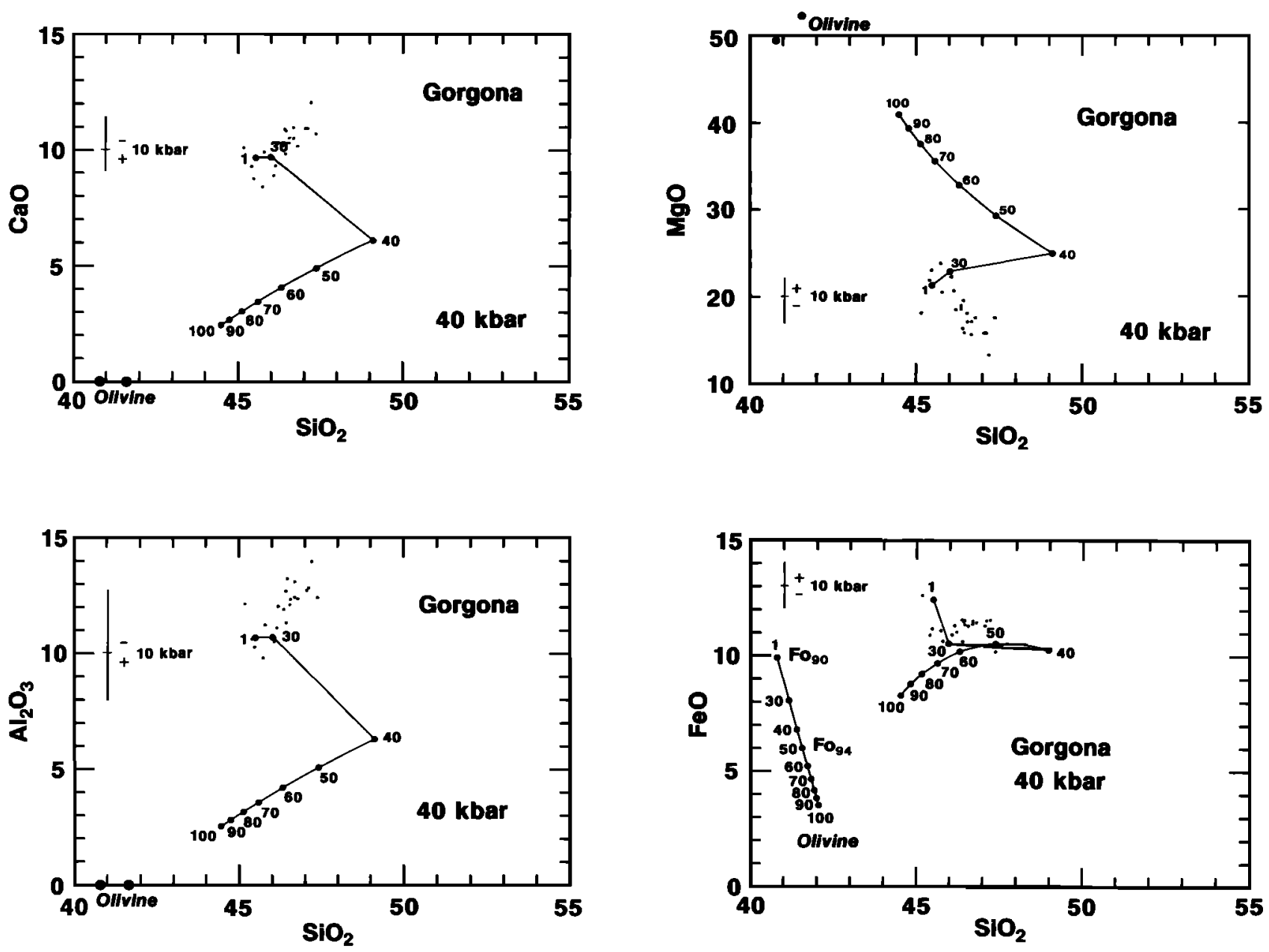

Fig. 10. Liquid compositions formed by 1 to $100 \%$ melting of average mantle peridotite at $40 \mathrm{kbar}$, compared to the geochemistry of Gorgona komatiiles (weight \%). Phase relations are shown in Figure $9 a$. Liquids are valid for the system CMFAS; $\mathrm{Na}_{2} \mathrm{O}$ will lower $\mathrm{MgO}$ (see text).

changes occur in the composition of the liquid, particularly for $\mathrm{CaO}, \mathrm{Al}_{2} \mathrm{O}_{3}$, and $\mathrm{SiO}_{2}$ (Figure 10). The content of $\mathrm{SiO}_{2}$ increases because of the dissolution of orthopyroxene in the melt, and reaches a maximum of $49 \%$. Mysen and Kushiro [1977] documented similar changes at $20 \mathrm{kbar}$; liquids formed by $<2 \%$ melting are nepheline normative with 44 to $45 \% \mathrm{SiO}_{2}$; liquids formed by $35 \%$ melting and in equilibrium with harzburgite $(\mathrm{L}+\mathrm{Ol}+\mathrm{Opx})$ have $51 \% \mathrm{SiO}_{2}$. Large variations were also reported for $\mathrm{CaO}$ and $\mathrm{Al}_{2} \mathrm{O}_{3}$ [Mysen and Kushiro, 1977].

Inspection of Figure 10 demonstrates that most of the Gorgona komatiites were formed by pseudoinvariant melting that did not exceeded $30 \%$. Garnet is expected to have been a residual phase for most komatiites $(\mathrm{L}+\mathrm{Ol}+\mathrm{Opx}+\mathrm{Cpx}+$ $\mathrm{Gt}$ ), and this is consistent with the observation of depletions in the heavy rare earth elements $(\mathrm{Gd} / \mathrm{Yb}>1$ [Aitken and Echeverria, 1984]). Again, the pressure of partial melting was $40 \mathrm{kbar}$, about $130 \mathrm{~km}$ depth.

\subsection{Munro-Type Komatiites}

Inspection of Figure $8 a$ shows that many of the Munro-type komatiites are similar in composition to liquids at the $50 \mathrm{kbar}$ pseudoinvariant point $\mathrm{L}+\mathrm{Ol}+\mathrm{Opx}+\mathrm{Cpx}+\mathrm{Gt}$. The content of $\mathrm{MgO}$ is 23 to $25 \%$ (Table 5), and it is therefore possible to interpret these as primary magmas. The spectrum of compositions radiate to and from olivine, consistent with the addition and removal of olivine from a $50 \mathrm{kbar}$ partial melt. But this interpretation is neither unique nor without its difficulties.

Another possibility is that the Munro komatiites were all residual liquids formed by extensive $(\mathrm{L}+\mathrm{Ol}$ ) or total $(\mathrm{L})$ melting of mantle peridotite. Figure $8 a$ shows that they could have formed by fractionation of variable amounts of olivine from a liquid with the composition of mantle peridotite. Most of the Munro-type komatiites have contents of $\mathrm{MgO}$ that exceed $24 \%$, and these project to the olivine-rich side of the $50 \mathrm{kbar}$ pseudoinvariant point (Figure 8a). Although some can be explained as olivine cumulates in a 50 kbar partial melt, Bickle [1982] has demonstrated that komatiites having 27 to $30 \% \mathrm{MgO}$ could have been cumulate-free liquids. Since these highly magnesian liquids are not coincident with a high pressure invariant point, the logical interpretation is that they formed by very high degrees of melting. For the cases where melting is total $(\mathrm{L})$, high $(\mathrm{L}+\mathrm{Ol})$, or moderate $(\mathrm{L}+\mathrm{Ol}+\mathrm{Opx})$, the contents of $\mathrm{CaO}$ and $\mathrm{Al}_{2} \mathrm{O}_{3}$ in komatiites are inherited from the peridotite source. And since $\mathrm{CaO} /\left(\mathrm{CaO}+\mathrm{Al}_{2} \mathrm{O}_{3}\right)$ for average mantle peridotite and partial melts at $50 \mathrm{kbar}$ are similar purely by chance, it is possible to conclude that komatiites plot near the $50 \mathrm{kbar}$ invariant point also by chance.

We therefore have two possible interpretations for the Munro komatiites based strictly on $\mathrm{CaO} /\left(\mathrm{CaO}+\mathrm{Al}_{2} \mathrm{O}_{3}\right)$. Either they were partial melts from $50 \mathrm{kbar}$ that had experienced 
olivine addition and subtraction, or they were all residual liquids formed by variable olivine removal from an extensively melted peridotite source. This problem is important to resolve because the implications are enormous. Miller et al. [1991b] demonstrated that mantle peridotite would have to melt at pressures in the lower mantle ( $>200 \mathrm{kbar}$ ) in order to be totally or extensively molten at the surface. This in turn would place profound constraints on the composition of the lower mantle. However, a komatiite formed by lower degrees of melting at 50 kbar does not constrain the geochemical structure of the source region. In order to evaluate which of these two possibilities is erroneous, a more detailed examination is now made of the partial melting possibility, with degrees of partial melting that range from $1 \%$ to $100 \%$. The phase diagram is shown in Figure $9 b$, and the results are shown in Figure 11.

An additional complication that has made the Munro-type komatiites difficult to understand is that there is such a wide range of compositions, with $\mathrm{SiO}_{2}$ that ranges from $44 \%$ to 51 $\%$, and $\mathrm{CaO}$ and $\mathrm{Al}_{2} \mathrm{O}_{3}$ that both range from $4 \%$ to $10 \%$ (Figure 11). This variation cannot be explained simply by olivine addition and removal from a single parental composition or by alteration (see appendix). However, Figure 11 shows that this spectrum of compositions can be explained by addition and subtraction of olivine from a spectrum of liquids formed by 35 to $44 \%$ melting of average mantle peridotite.
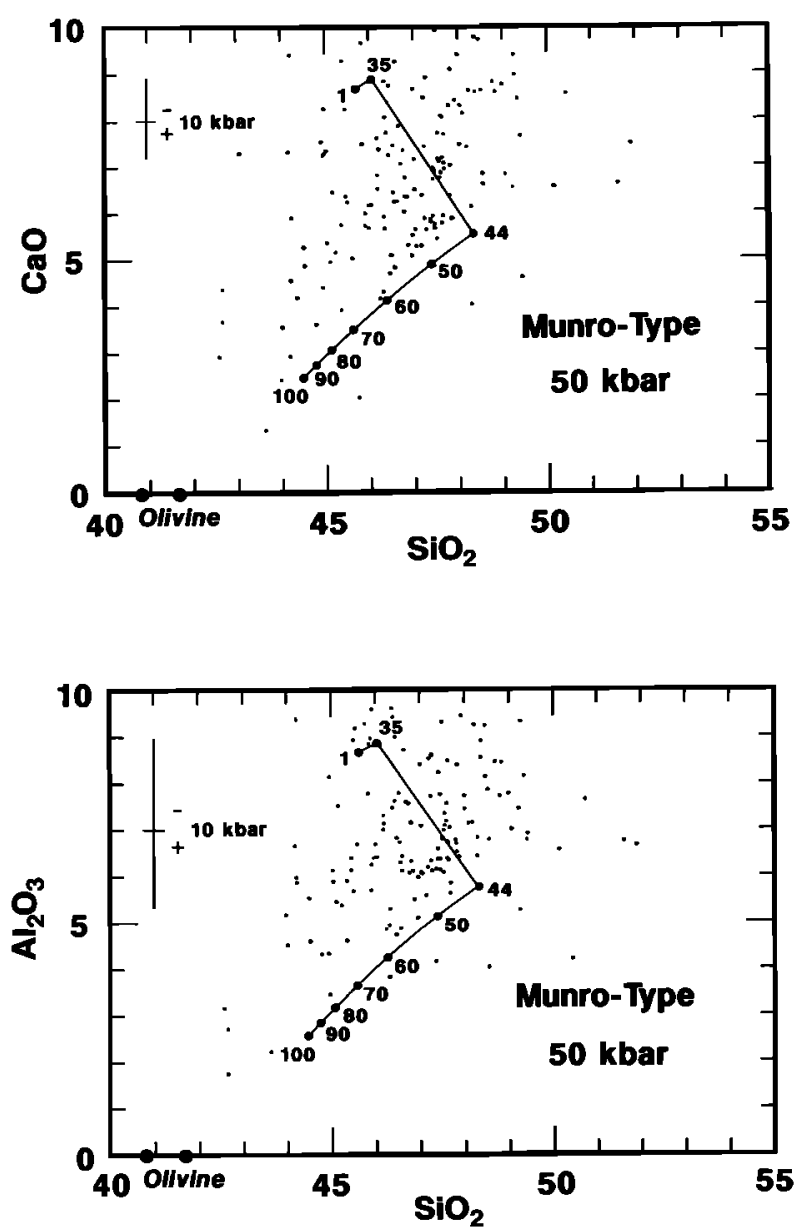

At $50 \mathrm{kbar}$, the partial melting of average mantle peridotite on the solidus will involve the assemblage $\mathrm{L}+\mathrm{Ol}+\mathrm{Opx}+$ $\mathrm{Cpx}+\mathrm{Gt}$ and the degree of melting will range from about 1 to $35 \%$. The geochemical characteristics of these initial liquids are $\mathrm{CaO} /\left(\mathrm{CaO}+\mathrm{Al}_{2} \mathrm{O}_{3}\right)=0.50 ; \mathrm{MgO}=23$ to $25 \%$; and $\mathrm{SiO}_{2}$ $=45-46 \%$. When the degree of partial melting exceeds 35 $\%$, clinopyroxene is the first phase to be consumed $(\mathrm{L}+\mathrm{Ol}+$ Opx + Gt; Figure 9b). CaO and $\mathrm{Al}_{2} \mathrm{O}_{3}$ change slightly until the degree of partial melting reaches $36 \%$, at which point $\mathrm{CaO} /\left(\mathrm{CaO}+\mathrm{Al}_{2} \mathrm{O}_{3}\right)$ of the liquid is 0.49 , defined by the peridotite source. Progressive melting will proceed up the harzburgite cotectic $\mathrm{L}+\mathrm{Ol}+\mathrm{Opx}$ after garnet has been exhausted. This scenario is very similar to the one discussed above for the origin of the Gorgona komatiites at $\mathbf{4 0} \mathrm{kbar}$. It is during the progressive melting of harzburgite where large changes occur for $\mathrm{CaO}, \mathrm{Al}_{2} \mathrm{O}_{3}$, and $\mathrm{SiO}_{2}$ in the liquid (Figure 10), even though $\mathrm{CaO} /\left(\mathrm{CaO}+\mathrm{Al}_{2} \mathrm{O}_{3}\right)$ remains at 0.49 , defined by the peridotite source. Changes in $\mathrm{MgO}$ are more modest, increasing from $25 \%$ to $27 \%$. The content of $\mathrm{SiO}_{2}$ increases to $49 \%$, and this increase occurs because orthopyroxene is being dissolved into the melt. Further melting will involve only olivine $(\mathrm{L}+\mathrm{Ol})$, and its dissolution will cause $\mathrm{SiO}_{2}$ to drop. Inspection of Figure 11 shows that most Munro-type komatiites can be described by addition and subtraction of olivine from liquids that had harzburgite in the residue (i.e., $\mathrm{L}+\mathrm{Ol}+\mathrm{Opx}$ ),
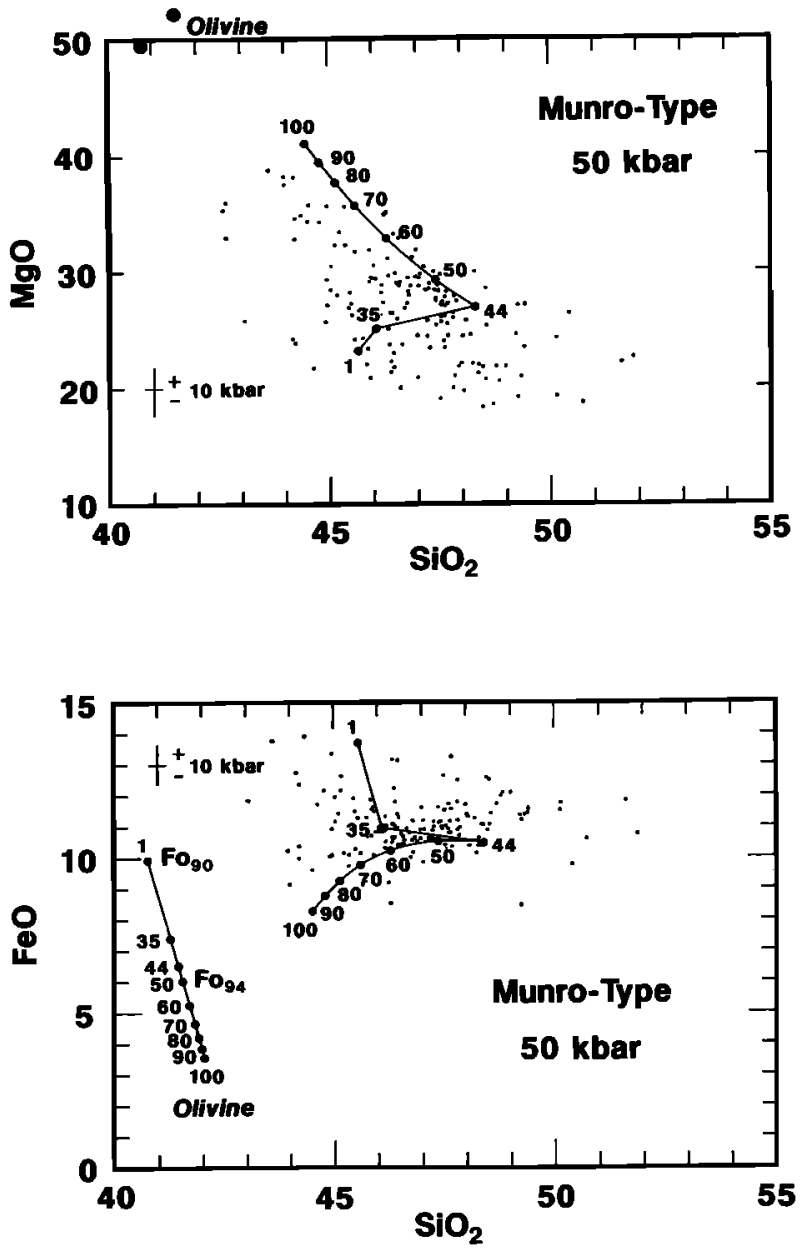

Fig. 11. Liquid compositions formed by 1 to $100 \%$ melting of average mantle peridotite at 50 kbar, compared to the geochemistry of Munro-type komatiites (weight \%). Phase relations are shown in Figure $9 b$. Liquids are valid for the system CMFAS. 
and that the degree of partial melting ranged from about 35 to 44 $\%$. The absence of garnet in the residue is consistent with the rare earth evidence, which shows no depletions in the heavy rare earth elements [Arth et al., 1977; Jahn et al., 1980].

Although this analysis has been restricted to the partial melting of average mantle peridotite, it is also possible that the source region contained a considerable amount of harzburgite sensu stricto $(\mathrm{Ol}+\mathrm{Opx})$ in addition to lherzolite $(\mathrm{OI}+\mathrm{Opx}+$ Cpx $+\mathrm{Gt})[D$. Canil, personal communication, 1991]. If correct, the spectrum of Munro komatiites could have formed by degrees of melting that were lower than the estimates given above, that is $<40 \%$.

So far we have considered melting at $50 \mathrm{kbar}$; but inspection of Figure 10 illustrates that this scenario could have operated also at $\mathbf{4 0} \mathrm{kbar}$. For liquids that have a harzburgite residue $(\mathrm{L}+\mathrm{Ol}+\mathrm{Opx})$, the parameter $\mathrm{CaO} /\left(\mathrm{CaO}+\mathrm{Al}_{2} \mathrm{O}_{3}\right)$ is defined largely by the composition of the source region. In this case, pressure information is lost because Munro komatiites could have had harzburgite residues from 25 to $80 \mathrm{kbar}$. The actual pressure of melting is therefore subject to considerable uncertainty. However, a number of lines of evidence indicate that $\mathbf{5 0} \mathrm{kbar}$ is probably realistic. If the pressure was as low as $25 \mathrm{kbar}$ or so, initial liquids and those for harzburgite residues will be too low in $\mathrm{MgO}$. Conversely, if the pressure of melting was near $80 \mathrm{kbar}$, the $\mathrm{SiO}_{2}$ content would be too high (Table 5, Figure 12).

It is also possible to explain the geochemistry of the Munro komatiites as residual liquids from high degree $(\mathrm{L}+\mathrm{Ol})$ or from total melts (L), but it requires some special circumstances. Although not explicity shown in Figure 11, residual liquids formed by fractional crystallization of olivine from a liquid having the composition of average mantle peridotite would define a track similar to, but not identical with, the equilibrium L + Ol track (44 - $100 \%$; Figure 11). There would be only one way to explain a komatiite that did not have a composition on this track. For a komatiite that is low in both $\mathrm{MgO}$ and $\mathrm{SiO}_{2}$, that is one with the characteristics of an initial melt at $50 \mathrm{kbar}$ (i.e., $24 \% \mathrm{MgO}$ and $46 \% \mathrm{SiO}_{2}$ ), the source region would have to be lower in $\mathrm{SiO}_{2}$ than average mantle peridotite.

Our world data base of 668 peridotites yields an average of $44.47+/-2 \%$ (two standard deviations), so there exist real variations in silica in the mantle. If these high degree melting arguments are applied to the Gorgona komatiites, which are Munro-like in that $\mathrm{CaO} /\left(\mathrm{CaO}+\mathrm{Al}_{2} \mathrm{O}_{3}\right)$ is similar to mantle peridotite, then we may anticipate wide variations in their geochemistry also. But inspection of Figure 10 shows that the geochemistry of the Gorgona komatiites is quite restricted. This means that if indeed they were formed by high degrees of melting instead of by pseudoinvariant melting, the source region must have been very homogeneous with respect to the major elements.

We are left with the unfortunate conclusion that the geochemistry of the Munro-type komatiites is compatible with both very high (e.g., $100 \%$ ) and moderate degrees (35 - $44 \%$ ) of partial melting. But the essential difficulty with the high melt fraction scenario is that it would have required a unique source region to explain each Munro komatiite and fails, therefore, on grounds of improbability.

\subsection{Barberton Komatiites}

When initial melting occurs at pressures that are greater than $50 \mathrm{kbar}$, the liquids will begin to have affinities with the
Barberton komatiites, characteristically high in $\mathrm{CaO} /(\mathrm{CaO}+$ $\mathrm{Al}_{2} \mathrm{O}_{3}$ ). But before we can proceed with an igneous interpretation of these rocks, an assessment must be made of the effect of alteration on $\mathrm{CaO} /\left(\mathrm{CaO}+\mathrm{Al}_{2} \mathrm{O}_{3}\right)$ [Smith and Erlank, 1982]. This has been the subject of considerably scrutiny by de Wit et al. [1987], and an expansion of their discussion is given in the appendix. Alteration by circulating hydrothermal solutions tends to strip from a rock significant amounts of $\mathrm{CaO}$ and $\mathrm{SiO}_{2}$, a process that appears to have affected the Barberton komatiites more than most Munro-types. Removal of $\mathrm{CaO}$ is usually not accompanied by a local gain in $\mathrm{CaO}$, so the system is open on an outcrop scale; alteration therefore tends to lower $\mathrm{SiO}_{2}$ and $\mathrm{CaO} /\left(\mathrm{CaO}+\mathrm{Al}_{2} \mathrm{O}_{3}\right)$. Pressures estimated from $\mathrm{CaO} /\left(\mathrm{CaO}+\mathrm{Al}_{2} \mathrm{O}_{3}\right)$ will therefore be minimum possible bounds. The samples projected in Figure $8 b$ are the least altered, about $50 \%$ of the Barberton data base (appendix).

Figure $8 b$ demonstrates that many Barberton komatiites have the compositions of liquids at a pseudoinvariant point involving $\mathrm{L}+\mathrm{Ol}+\mathrm{Gt}+\mathrm{Cpx}$ in the 80 - to $100-\mathrm{kbar}$ range; the spectrum of komatiites radiate to and from olivine, indicating that some are liquids that have gained and lost olivine. Partial melting at $100 \mathrm{kbar}$ has been modeled, and the results are shown in Figure $9 c$ and Figure 12. Melting involves the assemblage $\mathrm{L}$ $+\mathrm{Ol}+\mathrm{Gt}+\mathrm{Cpx}$ and, although orthopyroxene does not participate, the modeling was simplified by using an intial liquid composition for the peritectic equilibrium $\mathrm{L}+\mathrm{Ol}+\mathrm{Opx}+$ $\mathrm{Cpx}+\mathrm{Gt}$. As explain above, use of this composition will result in $\mathrm{MgO}$ that is too low and $\mathrm{SiO}_{2}$ that is too high, a problem that will not seriously affect the conclusions that follow.

A $1 \%$ melt fraction will have about $3.5 \% \mathrm{Al}_{2} \mathrm{O}_{3}$ and 27 $\% \mathrm{MgO}$ (Table 5), but does not quite match the geochemistry of Barberton komatiites because $\mathrm{SiO}_{2}$ is too low (Table 5; Figure 12). To increase $\mathrm{SiO}_{2}$ to the levels observed, the degree of partial melting must have been high. But because orthopyroxene is not involved, the only way this can be achieved is by high degrees of pseudoinvariant melting on the solidus $(\mathrm{L}+\mathrm{Ol}+\mathrm{Gt}$ $+\mathrm{Cpx}$ ) involving a source region that was also fairly high in $\mathrm{SiO}_{2}$. Although the composition of the source region does not directly affect the composition of liquids formed on the solidus, it does affect the degree of partial melting that is possible. Higher degree initial melts will be higher in $\mathrm{MgO}, \mathrm{MgO} / \mathrm{FeO}$, and $\mathrm{SiO}_{2}$ (Table 5), even for liquids that are strictly pseudoinvariant. Average mantle peridotite is not a good source region because pseudoinvariant melting could not have exceeded $35 \%$. But for the primitive mantle peridotite chosen, which is Ib8 of Stosch and Seck [1980], initial melting can reach up to 52 $\%$ (Figure 9c). The liquid produced has about $31 \% \mathrm{MgO}$ and $47 \% \mathrm{SiO}_{2}$ (Figure 12), and successfully reproduces the geochemistry of many Barberton komatiites. Again the spectrum of komatiites can be explained by olivine addition and substraction from this composition.

Melting in excess of $52 \%$ is very unusual. Clinopyroxene will be first phase to be consumed, and advanced melting will proceed up the cotectic $\mathrm{L}+\mathrm{Ol}+\mathrm{Gt}$ (Figure 9c). When this occurs, there will actually be an increase in $\mathrm{Al}_{2} \mathrm{O}_{3}$ in the liquid because the $\mathrm{Al}_{2} \mathrm{O}_{3}$ content of the primitive mantle source is higher than initial Barberton liquids (Figure 12). Barberton komatiites could not have formed from these high degree liquids. The next phase to be consumed is predicted to be olivine, and garnet will be the liquidus phase for Ib8 at $100 \mathrm{kbar}$ (Figure $9 \mathrm{c}$ ). However, the crystallization interval of garnet only $(L+G t)$ is likely to be only some tens of degrees, and the liquid trajectory 

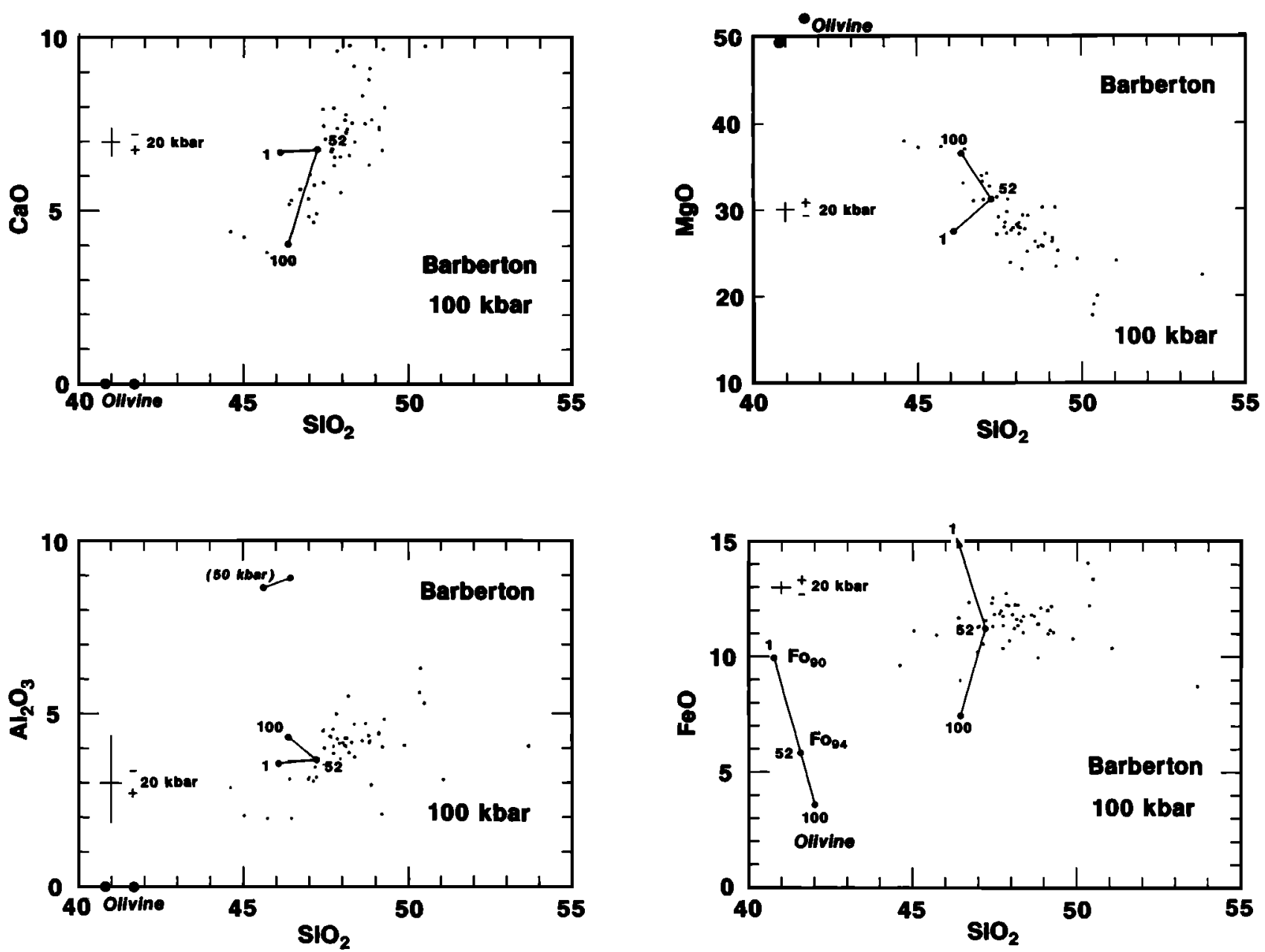

Fig. 12. Liquid compositions formed by 1 to $100 \%$ melting of primitive mantle peridotile [Ib8 Stosch and Seck, 1980], compared to the geochemistry of Barberton komatiites (weight \%). Phase relations are shown in Figure $9 c$. Liquids are valid for the system CMFAS.

from 52 to $100 \%$ melting in Figure 12 was treated as if $1 \mathrm{lb} 8$ was multiply saturated in olivine and garnet $(\mathrm{L}+\mathrm{Ol}+\mathrm{Gt})$ at all temperatures between the liquidus and the solidus.

A Barberton komatiite formed as a partial melt at $100 \mathrm{kbar}$ would have had garnet in the source region (i.e., $\mathrm{L}+\mathrm{Ol}+\mathrm{Gt}$ $+\mathrm{Cpx}$ ). The importance of garnet was discussed in the pioneering articles of Green [1975], Sun and Nesbitt [1978], Nesbitt et al., [1979], and Jahn et al., [1982], and this was based on the observation that high $\mathrm{CaO} /\left(\mathrm{CaO}+\mathrm{Al}_{2} \mathrm{O}_{3}\right)$ is accompanied by depletions in the heavy rare earth elements (e.g., high $\mathrm{Gd} / \mathrm{Yb}$ ). However, there has been less agreement has to the mechanism by which garnet was removed. The general possiblities that have been discussed are (1) garnet was retained as the residual phase or fractionated somehow during the time of melting [Green, 1975; Sun and Nesbitt, 1978; Ohtani, 1984; Arndt, 1986], (2) the source region had inherited the geochemical signature of a prior stage of garnet removal by, for example, removal in an early magma ocean, and garnet did not necessarily play a role during magma genesis [Jahn et al., 1982; Cawthorn and Strong, 1974; Ohtani et al., 1989]. The nearly chondritic initial isotopic, ratios reported for both hafnium [Gruau et al., 1990a] and neodymium [Gruau et al., 1990b] in Barberton komatiites is strong support for the residuum interpretation. This is in complete accord with our phase equilibrium results which show that garnet was fractionated as a residual phase $(\mathrm{L}+\mathrm{Ol}+\mathrm{Gt}+\mathrm{Cpx})$ during partial melting.

\section{EFFECTS OF DECOMPRESSION ON THE GEOCHEMISTRY OF KOMATITE}

Although isobaric phase diagrams like Figure 9 are useful for examining how the geochemistry of a komatiite is affected by advanced melting above the solidus, they are geophysically unrealistic because the melting of mantle peridotite cannot proceed from initial to total isobarically. It is triggered when the mantle advects adiabatically and intersects the solidus, and the parcel of magma will follow a new adiabatic T-P path which connects the temperatures and pressures of melt initiation on the solidus to eruption temperature at the surface. These concepts were applied to the generation of basaltic magmas at low pressures [McKenzie, 1984; McKenzie and Bickle, 1988], and more recently to the generation of komatiites at elevated pressures [Miller et al., 1991a, b].

Adiabatic T-P trajectories for komatiite magmas are shown in Figure 13. The komatiites formed on the solidus at 40 to 100 kbar have been connected to eruption temperatures by means of the adiabatic trajectories given in Miller et al. [1991b]. Figure 13 differs from the work of Miller et al. [1991b] only in that the melting temperatures for KLB1 determined at Stony Brook [Herzberg et al., 1990; McFarlane et al., 1990] are higher thán those reported by Takahashi [1986]. The important point is that the adiabatic $d T / d P$ trajectories approximately parallel $d T / d P$ for the olivine liquidus at pressures below about $50 \mathrm{kbar}$. If they 


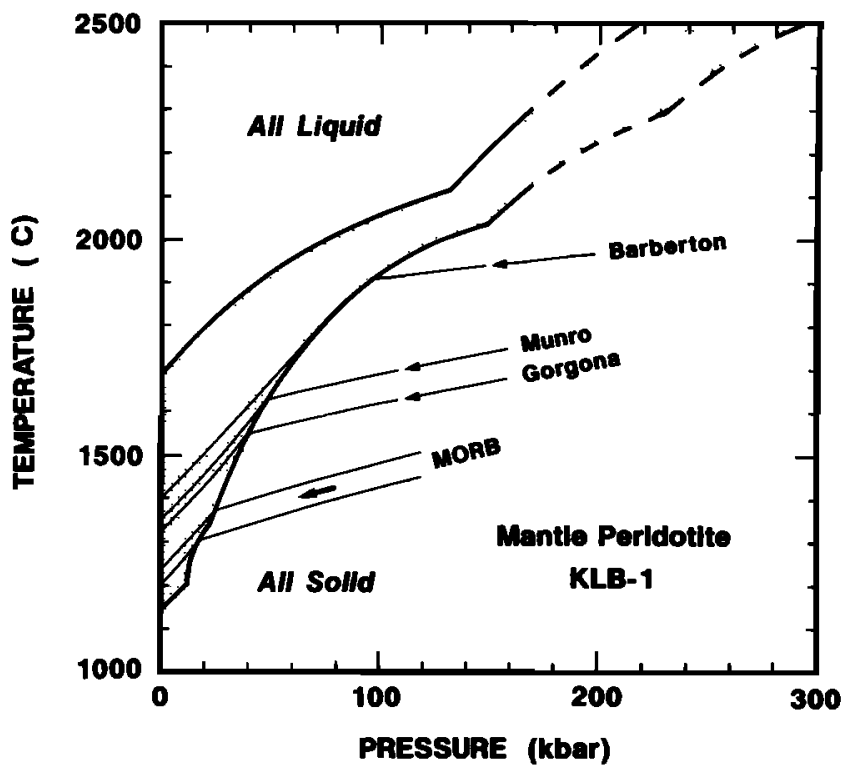

Fig. 13. Adiabatic trajectories and depths of melting inferred for Gorgona, Munro, and Barberton komatiites. The solidus and liquidus lemperatures for KLBl are based on experimental data of Takahashi [1986] adjusted to higher temperatures observed by Herzberg et al. [1990] and McFarlane et al. [1990] and unreported data. Broken lines are extrapoiated solidus and liquidus locations. Adiabatic trajectories are based on the work of Miller et al. [1991b]. MORB adiabal is bounded between the $1280^{\circ} \mathrm{C}$ potential temperature of McKenzie and Bickle [1988] and slightly higher temperatures indicated by garnet in the source region [Salters and Hart, 1989]. Deflections in the adiabats due to the olivinemodified spinel transformation are not shown.

are precisely parallel then it follows that olivine can be neither melted nor crystallized, and there can be no change in the melt fraction with decompression. Additionally, the composition of the erupted magma would be identical to the primary magma formed on the solidus. This may explain why many Gorgona and Barberton komatiites are so geochemically similar to their primary magmas formed at 40 and $100 \mathrm{kbar}$ respectively. The principal modifications have been in terms of olivine addition and subtraction, a process that could have occurred by settling after eruption on the surface.

A reduction in pressure simultaneously lowers $d T / d P$ of the adiabats [McKenzie and Bickle, 1988; Miller et al., 1991b] and raises $d T / d P$ of the olivine liquidus (Figure 13). This combined effect can result in an increased melt fraction with decompression, the magnitude of which will depend on a precise location of the adiabat; these are difficult to determine with precision for trajectories that are located between the liquidus and solidus [Miller et al., 1991b]. This kind of information is needed in order to understand how the Munro komatiites could have evolved from initial melts to larger melt fractions in equilibrium with harzburgite; at 50 kbar the melt fraction must increase from $35 \%$ to $44 \%$ (Figure 11). But at $40 \mathrm{kbar}$, the melt fraction needed to form similar high $\mathrm{SiO}_{2}$ komatiite magmas drops to about $40 \%$ (Figure 10). The wide spectrum of Munro komatiite compositions can then be explained by melting that varied from $35 \%$ at $50 \mathrm{kbar}$ to $40 \%$ at $40 \mathrm{kbar}$. The important point is that small increases in melting attending adiabatic decompression can cause large changes in the geochemistry of komatiites when harzburgite is either the source or the residue from a more fertile source.

The 80 to 100 kbar pressures of melting for the Barberton komatiites are similar to the 80 to $90 \mathrm{kbar}$ pressure of neutral buoyancy between olivine and magmas [Agee and Walker, 1988; Miller et al., 1991a]. It is within this high pressure region where melting could be mostly equilibrium rather than fractional [Herzberg, 1984]. The density contrast will increase upon adiabatic decompression, and this will create opportunities for the melt to fractionate by segregation into pools [Arndt, 1986]. The 80 to $100 \mathrm{kbar}$ inferred from the geochemistry of the Barberton komatiites could be recording only the final stages in equilibrium melting prior to separation of the liquid from its matrix, and the actual pressure of melt initiation may have been even greater.

\section{Formation Of Komatites In Plumes}

Thermal models point to an Archean mantle with a mean temperature that was only 100 to $150^{\circ} \mathrm{C}$ higher than at present [Turcott, 1980; Jarvis and Campbell, 1983; Campbell and Jarvis, 1984], and komatiites could have formed by melting in hot rising plumes [Jarvis and Campbell, 1983; Arndt, 1986; Campbell et al., 1989; Miller et al., 1991a,b]. These would have differed from present-day hot spots to the extent that the plumes intersected the solidus greater depths. An obvious corollary to this model is that the Earth was largely solidified throughout the Archean, and this has considerable support in the isotopic compositions of the earliest Archean basalts, komatiites, and continental crust. The mantle source regions of these rocks had high Sm/Nd [Shirey and Hanson, 1986; McCulloch and Compston, 1981], and this is most simply interpreted as a depletion event caused by approximately 10 to $20 \%$ partial melting of a fully solidified mantle soon after the Earth first formed [Arndt, 1986; Chase and Patchett, 1988; Galer and Goldstein, 1991; Smith and Ludden, 1989]. Although there is considerable evidence for a magma ocean stage of Earth history [Wetherill, 1990, Stevenson, 1987; Herzberg and Gasparik, 1991], the isotopic data and thermal modeling [Miller et al., $1991 b$ ] indicate that it solidified early, well before the onset of the Archean [see also Arndt, 1986].

The formation of the Barberton komatiites at pressures equal to or greater than the 80 to $90 \mathrm{kbar}$ pressure of neutral buoyancy between olivine and magmas [Agee and Walker, 1988; Miller et al., 1991a] demonstrates that there existed no density barrier to the eruption of komatiitic magmas in the Archean. If komatiites formed by percolation in a passive matrix like present-day MORB volcanism [e.g., Takahashi, 1990], it is difficult to understand how they could have erupted to the surface from $300 \mathrm{~km}$ depth. Arndt [1986] and Miller et al. $[1991 a, b]$ addressed this dilema by considering an origin in mantle plumes or diapirs. Thermal buoyancy drives a plume because the temperature in it is higher than that of ambient mantle outside, and the plume will continue to rise even if a parcel of komatiite liquid within it is denser than a coexisting olivine crystal. The work of Miller et al. [1991a] indicates that komatiite and peridotite liquids have lower densities than the present-day bulk mantle to $400 \mathrm{kbar}$, a possible exception being a similarity in densities at around 133 kbar. Barberton komatiites contained within a hot plume would have been less dense than the ambient mantle at $100 \mathrm{kbar}$.

Compared to the present-day Earth, excess temperatures in a $3.5 \mathrm{Ga}$ Barberton plume would have been about $500^{\circ} \mathrm{C}$, and excess temperatures in a $2.7 \mathrm{Ga}$ Munro plume about 250 to $300^{\circ} \mathrm{C}$ (Figure 13). However, if the Archean mantle was 100 to $150^{\circ} \mathrm{C}$ hotter than at present [Jarvis and Campbell, 1983; Turcotte, 1980], excess temperatures in Archean plumes would have been correspondingly lower, about 150 to $350^{\circ} \mathrm{C}$ above 
ambient mantle temperatures. These are very similar to 200 to $300^{\circ} \mathrm{C}$ excess temperatures that have been recommended for the present-day Hawaiian and Icelandic plumes [Sleep, 1990; McKenzie, 1984; Griffiths and Campbell, 1991; Watson and McKenzie, 1991; Liu and Chase, 1989].

Melt initiation will occur at $40 \mathrm{kbar}$ if present-day plumes have an excess temperature that is $200^{\circ}$ above the $1280^{\circ} \mathrm{C}$ MORB potential temperature [McKenzie and Bickle, 1988; Figure 13], and the primary magmas produced will be Gorgona-type komatiites with about $20 \% \mathrm{MgO}$. But the volcanic rocks from Hawaii are typically basaltic instead. Clague et al. [1991] reported $15 \% \mathrm{MgO}$ in Hawaiian picritic glasses, and recommended a primary magma with $17 \% \mathrm{MgO}$. These have $\mathrm{CaO} /\left(\mathrm{CaO}+\mathrm{Al}_{2} \mathrm{O}_{3}\right)$ and a major element chemistry that is similar to liquids formed at 25 to $30 \mathrm{kbar}$ [Elthon and Scarfe, 1984; Table 5], indicating an excess temperature of only about $100-150^{\circ}$ for Hawaii.

Attention is drawn to the possibility that the Gorgona komatiites were formed in plumes that rivaled the Munro plume in depth of melting. This is of special interest because Re-Os age dating [Walker et al., 1991] constrains the Gorgona komatijtes to be $155+/-43 \mathrm{Ma}$, late Jurassic to early Cretaceous. Walker et al. [1991] noted the coincidence in this age with the breakup of Pangea, and suggested that this event could have been caused by large-scale mantle upwelling. The error bars permit an equally intriguing possibility; that the Gorgona komatiites are early to mid Cretaceous in age (120 $\mathrm{Ma}$ ). If correct, they may have been a part of the Caribbean Plateau [Storey et al., 1991] formed by the Galapagos hot spot [Duncan and Hargraves, 1984]. An early Cretaceous age is also the time of formation of the gigantic oceanic plateaus in the Pacific [Larson, 1991; Tarduno et al., 1991]. At the present time, there is no information on the composition of the oceanic crust below such plateaus as Ontong Java. However, in addition to basalts, komatiites of Cretaceous age may be fairly abundant in oceanic plateaus throughout the Pacific, and may provide a good analogue for understanding komatiites in Archean greenstone belts [Storey et al.,1991].

Attention has also been drawn to possible secular variations in the geochemistry of komatiites [Jahn et al., 1982]. High $\mathrm{CaO} /(\mathrm{CaO}+\mathrm{Al} 2 \mathrm{O} 3)$ and $\mathrm{Gd} / \mathrm{Yb}$ characterize the early Archean komatiites from Barberton and the Pilbara block, and these have ages of about $3.5 \mathrm{Ga}$ [e.g., Gruau et al., 1990a]. Munro-type komatiites with mantle-like $\mathrm{CaO} /\left(\mathrm{CaO}+\mathrm{Al}_{2} \mathrm{O}_{3}\right)$ and $\mathrm{Gd} / \mathrm{Yb}$ were formed in the late Archean, about $2.7 \mathrm{Ga}$ ago [Nesbitt et al., 1979; Jahn et al., 1982; Gruau et al., 1990a], and the Gorgona komatiites are Mesozoic in age. The similarity in conditions of melting between the Gorgona and Munro komatiites (Figure 13), and the possibility of Munro-like volcanism in the Pacific of Cretaceous age, point to an interior that cooled marginally over the last 2.5 billion years. Secular cooling appears to have been expressed mainly in the early part of the Archean.

\section{CONCLuSIONS}

High pressure melting experiments on compositions in the system $\mathrm{CaO}-\mathrm{MgO}-\mathrm{Al}_{2} \mathrm{O}_{3}-\mathrm{SiO}_{2}$ demonstrate that liquids on the solidus are komatiitic in the 50-to 150 -kilobar pressure range. The effect of pressure is to expand the stability field of garnet at the expense of olivine, clinopyroxene, and orthopyroxene. This causes a very pronounced increase to occur in $\mathrm{CaO} /(\mathrm{CaO}+$ $\mathrm{Al}_{2} \mathrm{O}_{3}$ ) for liquids that are multiply saturated in $\mathrm{Cpx}+\mathrm{Gt}$, demonstrating that it is a good indicator of depth of melting. Addition of $\mathrm{FeO}$ does not affect $\mathrm{CaO} /\left(\mathrm{CaO}+\mathrm{Al}_{2} \mathrm{O}_{3}\right)$ of liquids at an isobaric invariant point, but it lowers the contents of $\mathrm{CaO}$, $\mathrm{Al}_{2} \mathrm{O}_{3}$, and $\mathrm{SiO}_{2}$. The $\mathrm{MgO}$ contents of liquids on the solidus are about $24 \%$ at $50 \mathrm{kbar}$ and $30 \%$ at $100 \mathrm{kbar}$.

The melting of peridotite from 1 to $100 \%$ has been simulated at a range of high pressures, and the liquids so produced have been compared to the geochemistry of komatiites. Komatiites from Gorgona Island can be understood as relatively low degree partial melts $(<30 \%)$, the products of pseudoinvariant melting involving $\mathrm{L}+\mathrm{Ol}+\mathrm{Opx}+\mathrm{Cpx}+\mathrm{Gt}$ on the solidus at 40 kilobars, about $130 \mathrm{~km}$ depth.

Munro-type komatiites are more difficult to understand. They have $\mathrm{CaO} /\left(\mathrm{CaO}+\mathrm{Al}_{2} \mathrm{O}_{3}\right)$ that is similar to low degree melts at $50 \mathrm{kbar}(\mathrm{L}+\mathrm{Ol}+\mathrm{Opx}+\mathrm{Cpx}+\mathrm{Gt})$, moderate degree melts $(\mathrm{L}+\mathrm{Ol}+\mathrm{Opx}$ ), or high degree melts $(\mathrm{L} ; \mathrm{L}+$ Ol). Because of this problem, the depth of melting for the Munro-type komatiites cannot be rigorously determined. And unlike the Gorgona komatiites, they contain a wide range of values for $\mathrm{CaO}, \mathrm{Al}_{2} \mathrm{O}_{3}$, and $\mathrm{SiO}_{2}$, variations that cannot be attributed simply to olivine addition and subtraction. This spectrum of compositions can be understood as liquids coexisting with a harzburgite residue ( $\mathrm{L}+\mathrm{Ol}+\mathrm{Opx})$ formed by $<40 \%$ melting of either average mantle peridotite or of harzburgite sensu stricto. Although the pressure of melting cannot be rigorously constrained, it was probably around $50 \mathrm{kbar}$, about $165 \mathrm{~km}$ depth. The difficulty with the high degree melting scenario $(\mathrm{L}+\mathrm{Ol})$ is that it would have required a unique source region to explain each Munro komatiite and fails, therefore, on grounds of improbability.

Komatiites from the Barberton Mountain Land have high $\mathrm{CaO} /\left(\mathrm{CaO}+\mathrm{Al}_{2} \mathrm{O}_{3}\right)$ and are similar to liquids formed by about $50 \%$ pseudoinvariant melting $(\mathrm{L}+\mathrm{Ol}+\mathrm{Gt}+\mathrm{Cpx})$ of fertile mantle peridotite in the 80 - to $100-\mathrm{kbar}$ range $(260-$ to $330-\mathrm{km}$ ).

Komatiites have been reasonably interpreted as the products of extensive or total melting of the mantle because they have a geochemistry that can be roughly explained by the removal of olivine from peridotite. But the results of this work point to problems with this interpretation. Instead, they can be more easily explained as partial melts $(<50 \%$ melting) with a geochemistry that was determined by high pressure crystal-liquid phase equilibria. An important corollary is that komatiites cannot be used to place constraints on the geochemistry of their source region, except in the most rudimentary way. This is unfortunate because it means that they cannot be used to probe the structure of the mantle, and address important questions concerning the geochemical properties of seismic discontinuities.

Secular variations in the geochemistry of komatiites could have formed in response to a reduction in the temperature and pressure of melting with time. The $3.5 \mathrm{Ga}$ Barberton komatiites and the $2.7 \mathrm{Ga}$ Munro-type komatiites could have formed in plumes that were hotter than the present-day mantle by $500^{\circ}$ and $300^{\circ}$, respectively. When excess temperatures are this size, melting is deeper and volcanism changes from basaltic to komatiitic. The komatites from Gorgona Island, which are Mesozoic in age, may be representative of komatiites that are predicted to occur in oceanic plateaus of Cretaceous age throughout the Pacific [Storey et al., 1991].

\section{APPENDIX}

With the exception of the extremely fresh komatiites from Zimbabwe [Nisbet et al., 1987], most have been 
metamorphosed to greenschist and amphibolite facies and have suffered variable amounts of alteration by hydrothermal solutions. An evaluation of these effects is required before confidence can be placed in any igneous interpretation. Smith and Erlank [1982] documented some possible problems in understanding $\mathrm{CaO}$ and $\mathrm{Al}_{2} \mathrm{O}_{3}$ in the Barberton komatiites, and de Wit et al. [1987] have documented important evidence for widespread mobilization of $\mathrm{Ca}$ and $\mathrm{Si}$, amongst others elements.

The effects of alteration on the geochemistry of volcanic rocks have been examined by laboratory experimentation and by carefully controlled field studies, and the reader is referred to the excellent discussion of this work in de Wit et al. [1987]. Experimental studies have monitored geochemical changes in seawater before and after reaction with rhyolite, andesite, basalt, and peridotite at elevated temperatures and pressures [e.g., Hajash and Chandler, 1981; Bischoff and Dickson, 1975; Hajash, 1975]. The results demonstrate that important quantities of $\mathrm{Ca}$ and $\mathrm{Si}$ can be removed from basalts and peridotites and $\mathrm{Mg}$ can be added. Studies have also been made on samples of fresh and hydrothermally altered pillow basalts from the MidAtlantic Ridge [Humphris and Thompson, 1978], and the results agree with the experimental work in that $\mathrm{Si}$ and $\mathrm{Ca}$ can be leached from the rock while $\mathrm{Mg}$ can be taken up. One of the important findings of the field studies is that mobilization of these elements is not confined to a hand specimen or outcrop scale. While leaching of $\mathrm{Ca}$ can be accompanied by localized precipitation, in general the system is open on an outcrop scale. This process has added important quantities of $\mathrm{Si}$ and $\mathrm{Ca}$ to the world's oceans, and resulted in the deposition of $\mathrm{Fe}, \mathrm{Mn}, \mathrm{Cu}$, and $\mathrm{Zn}$ on the sea floor [Von Damm et al., 1985; Hart, 1973; Reed, 1983].

These studies agree that $\mathrm{Ca}$ and $\mathrm{Si}$ are more mobile than $\mathrm{Al}$ in hydrothermal solutions. A positive correlation of $\mathrm{CaO} / \mathrm{Al}_{2} \mathrm{O}_{3}$ and $\mathrm{SiO}_{2}$ is therefore an indication of alteration. This is observed for the Barberton komatiites in Figure A1, and this supports the suggestion of de Wit et al. [1987] that $\mathrm{Ca}$ and $\mathrm{Si}$ have indeed been removed from the komatiites. The Munro komatiites are notable for having $\mathrm{CaO} / \mathrm{Al}_{2} \mathrm{O}_{3}$ equal to 1.0 [e.g., Jahn et al., 1982] and, unlike the Barberton komatiites, Figure A2 shows that it is largely independent of $\mathrm{SiO}_{2}$. It can be concluded from these comparisons that the Barberton komatiites were more severly affected by alteration than the Munro-types.

Addition and subtraction of olivine from a komatiitic magma cannot change $\mathrm{CaO} / \mathrm{Al}_{2} \mathrm{O}_{3}$. Pseudoinvariant melting can yield high pressure liquids with $\mathrm{CaO} / \mathrm{Al}_{2} \mathrm{O}_{3}$ and $\mathrm{SiO}_{2}$ that are higher than liquids generated at lower pressures. But to account for the spectrum of compositions in Figure A1 would require a range of pressures than span over $100 \mathrm{kbar}$, and is unreasonable on geological grounds. One other igneous process than can potentially explain the data is by advanced melting through the sequence $\mathrm{L}+\mathrm{Ol}+\mathrm{Cpx}+\mathrm{Gt}-->\mathrm{L}+\mathrm{Ol}+\mathrm{Gt}-->\mathrm{L}$ + Ol. In projection, highly magnesian komatiites from Barberton would differ from the others in having Munro-like $\mathrm{CaO} / \mathrm{Al}_{2} \mathrm{O}_{3}$. This observation was originally made by Smith and Erlank [1982], and correctly dismissed as another artifact of alteration because no change was observed for $\mathrm{Al}_{2} \mathrm{O}_{3} / \mathrm{TiO}_{2}$. This parameter is shown also in Figure A3. It can be seen that for Barberton komatiites having $\mathrm{CaO} / \mathrm{Al}_{2} \mathrm{O}_{3}>1.5$, the ratio $\mathrm{Al}_{2} \mathrm{O}_{3} / \mathrm{TiO}_{2}$ is typically around 11 , and this contrasts with about 20 for Munro-type komatiites [Jahn et al., 1982; Gruau et al., $1990 a$ ]. But for Barberton komatiites having $\mathrm{CaO} / \mathrm{Al}_{2} \mathrm{O}_{3}<1.5$, the ratio $\mathrm{Al}_{2} \mathrm{O}_{3} / \mathrm{TiO}_{2}$ stays either unchanged or it increases to

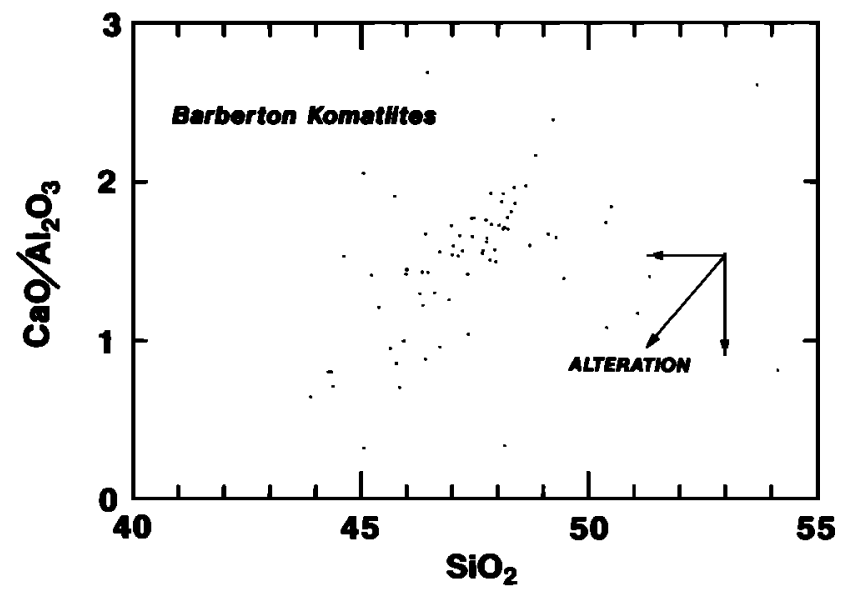

Fig. Al. $\mathrm{CaO} / \mathrm{Al}_{2} \mathrm{O}_{3}$ (weight \% ratio) versus $\mathrm{SiO}_{2}$ for Barberton komatiites.

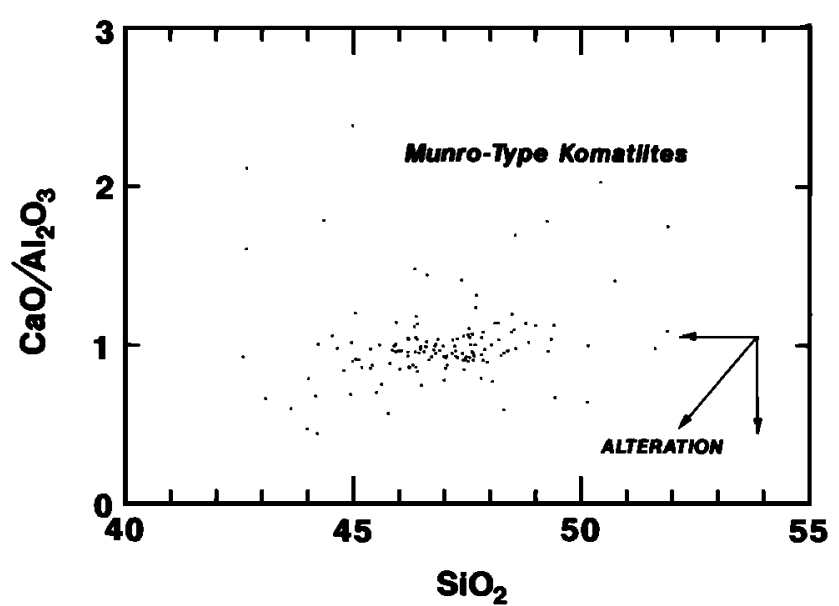

Fig. A2. $\mathrm{CaO} / \mathrm{Al}_{2} \mathrm{O}_{3}$ (weight \% ratio) versus $\mathrm{SiO}_{2}$ for Munro-type komatiites.

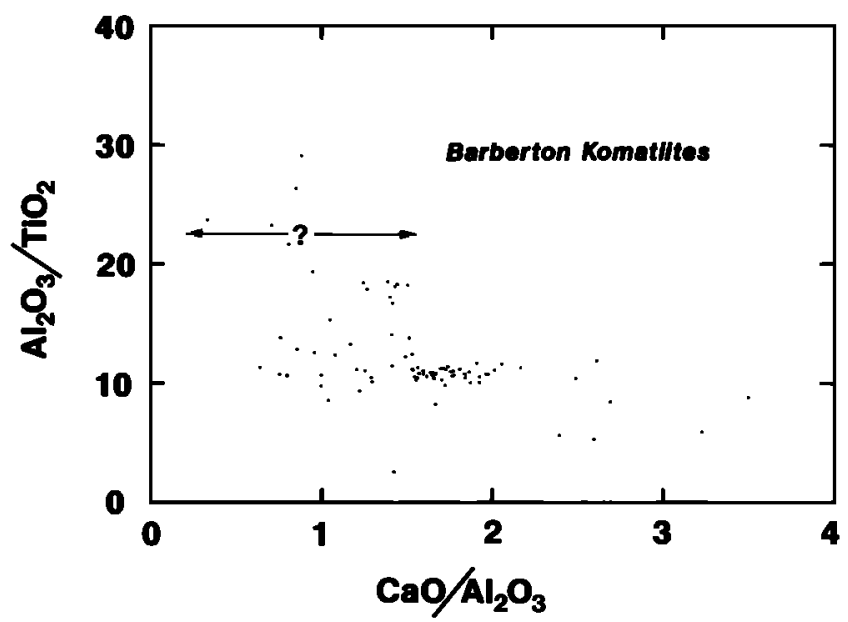

Fig. A3. $\mathrm{Al}_{2} \mathrm{O}_{3} / \mathrm{TiO}_{2}$ versus $\mathrm{CaO} / \mathrm{Al}_{2} \mathrm{O}_{3}$ (weight $\%$ ratios) for Barberton komatiites.

over 20. It is this part of the Barberton population that is suspect of being altered, and the highly scattered data have no obvious igneous explanation. Barberton komatiites with unusually high $\mathrm{Al}_{2} \mathrm{O}_{3} / \mathrm{TiO}_{2}$ may be bad analyses [N.T. Arndt, 
personal communication, 1991] or they may be an artifact of ' $\mathrm{Ti}$ removal during hydrothermal alteration. Barberton komatiites having $\mathrm{CaO} / \mathrm{Al}_{2} \mathrm{O}_{3}>$ than 1.5 are about $50 \%$ of the population, and are probably the least altered of the data base. The high pressure igneous interpretation offered above has been based on these "clean" Barberton samples.

Inspection of Figure 12 shows that the clean Barberton komatiites can be explain as liquids formed by about $52 \%$ pseudoinvariant melting at around $100 \mathrm{kbar}$. But a detailed examination of these plots shows that while this adequately explains $\mathrm{MgO}, \mathrm{Al}_{2} \mathrm{O}_{3}$, and $\mathrm{SiO}_{2}$ the contents of $\mathrm{CaO}$ that are predicted are mostly higher than those that are observed even for the clean Barberton data set. Although these differences are certainly within the experimental error of the high pressure data base, they may indicate that even the clean Barberton komatiites have lost some $\mathrm{CaO}$.

Acknowledgments. This research was supported by NSF grant EAR 89-16836 to C. Herzberg. The results on garnet and pyroxene were reported by Herzberg and Gasparik [1991], and supported in part by NSF EAR $90-03748$ to T. Gasparik. The high pressure experiments reported in this paper were performed in the Stony Brook High Pressure Laboratory which is jointly supported by the National Science Foundation (EAR 89-17563) and the State University of New York at Stony Brook. Thanks are extended to Nick Arndt and Dan McKenzie for critical comments on a first draft of this paper, and to Tibor Gasparik and Paul Hess for discussions.

\section{REFERENCES}

Agee, C.B., and D. Walker, Static compression and olivine floatation in ultrabasic silicate liquid, J. Geophys. Res., 93, 3437-3449, 1988.

Aitken, B.G., and L.M. Echeverria, Petrology and geochemistry of komatiites and tholeiites from Gorgona Island, Colombia, Contrib. Mineral. Petrol., 86, 94-105, 1984.

Anderson, D.L., Composition of the Earth, Science, 243, 367-370, 1989.

Andersen, O., The system anorthite-forsterite-silica, Am. J. Sci., 4th ser., 39, 407-454, 1915.

Arndt, N.T., Melting relations of ultramafic lavas (komatiites) at 1 atm and high pressure, Year Book Carnegie Inst. Washington, 75, 555$562,1976$.

Arndt, N.T., Ultrabasic magmas and high-degree melting of the mantle, Contrib. Mineral. Petrol. 64, 205-221, 1977.

Arndt, N.T., Komatiites: a dirty window to the Archean mantle, Terra Cognita, 6, 59-66, 1986.

Arndt, N.T., A.J. Naldrett, and D.R. Pyke, Komatiitic and iron-rich tholeiitic lavas of Munro Township, Northeast Ontario, J. Petrol., 18, 319-369, 1977.

Arth, J.G., N.T. Arndt, and A.J. Naldrett, Genesis of Archean komatiites from Munro Township, Ontario: trace element evidence, Geology, 5, 590-594, 1977.

Bertka, C., and J.R. Holloway, Martian mantle primary melts: an experimental study of iron-rich garnet lherzolite minimum melt composition, Proc. Lunar Planet. Sci. Conf., 18, 723-739, 1988.

Bickle, M.J., The magnesium contents of komatiitic liquids, In: Komatiites, edited by N.T. Arndt, and E.G. Nisbet, pp. 479-494, George Allen and Unwin, London, 1982.

Bickle, M.J., C.E. Ford, and E.G. Nisbet, The petrogenesis of peridotitic komatiites: evidence from high-pressure melting experiments, Earth Planet. Sci. Lett., 37, 97-106, 1977.

Bischoff, J.L., and F.W. Dickson, Seawater-basalt interaction at $200^{\circ} \mathrm{C}$ and 500 bars: implications for origin of sea-floor heavy-metal deposits and regulation of seawater chemistry, Earth Planet. Sci. Lett., 25, 385-397, 1975.
Boyd, F.R., Compositional distinction between oceanic and cratonic lithosphere, Earth Planet. Sci. Lett., 96, 15-26, 1989.

Brooks, C., and S.R. Hart, On the signficance of komatiite, Geology, 2, 107-110, 1974.

Campbell, I.H., and G.T. Jarvis, Mantle convection and early crustal evolution, Precambrian Res., 26, 15-56, 1984.

Campbell, I.H., R.W. Griffiths, and R.I. Hill, Melting in an Archaean mantle plume: heads it's basalts, tails it's komatiites, Nature, 339 , 697-699, 1989.

Cawthorn, R.G., and D.F. Strong, The petrogenesis of komatiites and related rocks as evidence for a layered upper mantle, Earth. Planet. Sci. Lell., 23, 369-375, 1974.

Chase, C.G., and P.J. Patchett, Stored mafic/ultramafic crust and early Archean mantle depletion, Earth Planet. Sci. Lett., 91, 66-72, 1988.

Clague, D.A., W.S. Weber, and J.E. Dixon, Picritic glasses from Hawaii, Nature, 353, 553-556, 1991.

Davis, B.T.C., The system Diopside-Forsterite-Pyrope at 40 kilobars, Year Book Camegie Inst. Washington, 63, 165-171, 1964.

Davis, B.T.C, and J.F. Schairer, Melting relations in the join diopside-forsterite-pyrope at 40 kilobars and at one atmosphere, Year Book Camegie Inst. Washington, 64, 123-126, 1965.

de Wit, M.J., R.A. Hart, and R.J. Hart, The Jamestown ophiolite complex, Barberton mountain belt: a section through $3.5 \mathrm{Ga}$ oceanic crust, J. African Earth Sci., 6, 681-730, 1987.

Duncan, R.A., and R.B. Hargraves, Plate tectonic evolution of the Caribbean region in the mantle reference frame, The Caribbean South American plate boundary and regional tectonics, Mem. Geol. Soc. Am., 162, 81-93, 1984.

Echeverria, L.M., Komatiites from Gorgona Island, Colombia, in: Komatiites, edited by N.T. Arndt and E.G. Nisbet, pp. 199-209, George Allen and Unwin, London, 1982.

Elthon, D., and C.M. Scarfe, High-pressure phase equilibria of a highmagnesia basalt and the genesis of primary oceanic basalts, $\mathrm{Am}$. Mineral., 69, 1-15, 1984.

Falloon, T.J., D.H. Green, C.J. Hatton, and K.L. Harris, Anhydrous partial melting of a fertile and depleted peridotite from 2 to $30 \mathrm{~kb}$ and application to basalt petrogenesis, J. Petrol., 29, 1257-1282, 1988.

Fujii, T., M. Tachikara, and K. Kurita, Melting experiments in the system $\mathrm{CaO}-\mathrm{MgO}-\mathrm{Al}_{2} \mathrm{O}_{3}-\mathrm{SiO}_{2}$ to $8 \mathrm{GPa}$ : Constraints to the origin of komatiites, Eos Trans. AGU, 70, 483, 1989.

Galer, S.J.G., and S.L. Goldstein, Early mantle differentiation and its thermal consequences, Geochim. Cosmochim. Acta, 55, 227-240, 1991.

Gansser, A., V.J. Dietrich, and W.E. Cameron, Palaeogene komatiites from Gorgona Island, Nature, 278, 545-546, 1979.

Gasparik, T., Transformation of enstatite-diopside-jadeite pyroxenes to garnet, Contrib. Mineral. Petrol., 102, 389-405, 1989.

Gasparik, T., Phase relations in the transition zone, J. Geophys. Res., 95, 15,751-15,769, 1990.

Green, D.H., Archean greenstone belts may include terrestrial equivalents of lunar maria?, Earth Planet. Sci. Lett., 15, 263-270, 1972.

Green, D.H., Genesis of Archean peridotitic magmas and constraints on Archean geothermal gradients and tectonics, Geology, 3, 15-18, 1975.

Green, D.H., and A.E. Ringwood, The genesis of basaltic magmas, Contrib. Mineral. Petrol., 15, 103-190, 1967.

Griffiths, R.W., and I.H. Campbell, On the dynamics of long-lived plume conduits in the convecting mantle, Earth. Planet. Sci. Lett., 103, 214-227, 1991.

Gruau, G., C. Chauvel, N.T. Arndt, and J. Cornichet, Aluminum depletion in komatiites and garnet fractionation in the early Archean mantle: Hafnium isotopic constraints, Geochim. Cosmochim. Acta, 54, 3095-3101, 1990a.

Gruau, G., C. Chauvel, and B.M. Jahn, Anomalous Sm-Nd ages for the early Archean Onverwacht Group Volcanics: Significance and petrogenetic implications, Contrib. Mineral. Petrol., 104, 27-34. $1990 b$.

Hajash, A., Hydrothermal processes along mid-ocean-ridges: an 
experimental investigation, Contrib. Mineral. Petrol., 53, 205-226, 1975.

Hajash, A., and G.W. Chandler, An experimental investigation of hightemperature interactions between seawater and rhyolite, andesite, basalt and peridotite, Contrib. Mineral Petrol., 78, 240-254, 1981.

Hart, R.A., Geochemical and geophysical implications of the reaction between seawater and the oceanic crust, Nature, 243, 76-78, 1973.

Herzberg, C.T., The solubility of olivine in basaltic liquids: an ionic model, Geochim. Cosmochim. Acta, 43, 1241-1251, 1979.

Herzberg, C.T., Chemical stratification in the silicate Earth, Earth Planet. Sci. Lett., 67, 249-260, 1984.

Herzberg, C., and T. Gasparik, Garnet and pyroxenes in the mantle: a test of the majorite fractionation hypothesis, J. Geophys. Res., 96, 16, 263-16,274, 1991.

Herzberg, C.T., and M.J. O'Hara, Origin of mantle peridotite and komatiite by partial melting, Geophys. Res. Lett., 12, 541-544, 1985.

Herzberg, C.T., and E. Ohtani, Origin of komatiite at high pressures, Earth Planet. Sci. Lett., 88, 321-329, 1988.

Herzberg, C.T., M. Feigenson, C. Skuba, and E. Ohtani, Majorite fractionation recorded in the geochemistry of peridotites from South Africa, Nature, 332, 823-826, 1988.

Herzberg, C., T. Gasparik, and H. Sawamoto, Origin of mantle peridotite: constraints from melting experiments to $16.5 \mathrm{GPa}, J$. Geophys. Res., 95, 15,779-15,803, 1990.

Hess, P.C., Komatiites and the Archean mantle (abstract), Proc. Lunar Planet. Sci. Conf., 21, 501-502, 1990.

Howells, S.,C. Begg, and M.J. O'Hara, Crystallization of some natural eclogites and garnetiferous ultrabasic rocks at high pressure and temperature, Phys. Chem. Earth, 9, 895-902, 1975.

Humphris, S.E., and G. Thompson, Hydrothermal alteration of oceanic basalts by seawater, Geochim. Cosmochim. Acta, 42, 107-125, 1978.

Ito, K., and G.C. Kennedy, Melting and phase relations in a natural peridotite to 40 kilobars, Am. J. Sci., 265, 519-538, 1967.

Jahn, B.-m., P. Vidal, and G.R. Tilton, Archean mantle heterogeneity: evidence from chemical and isotopic abundances in Archean igneous rocks, Philos. Trans. R. Soc. London A, 297, 353-364, 1980.

Jahn, B.-m., G. Gruau, and A.Y. Glikson, Komatiites of the Onverwacht Group, S. Africa: REE geochemistry, $\mathrm{Sm} / \mathrm{Nd}$ age and mantle evolution, Contrib. Mineral. Petrol., 80, 25-40, 1982.

Jarvis, G.T., and I.H. Campbell, Archean komatiites and geotherms: solution to an apparent contradiction, Geophys. Res. Lett., 10, 11331136, 1983.

Kushiro, I., Y.. Syono, and S. Akimoto, Melting of a peridotite nodule at high pressures and high water pressures, J. Geophys. Res., 73, 6023-6029, 1968.

Larson, R.L., Latest pulse of Earth: evidence for a mid-Cretaceous superplume, Geology, 19, 547-550, 1991.

Lesher, C.E., and D. Walker, Cumulate maturation and melt migration in a temperature gradient, J. Geophys. Res., 93 10, 295-10, 311, 1988.

Litvin, Y.A., High pressure melting relations in the garnet-lherzolitic system olivine-orthopyroxene-clinopyroxene-garnel, Phase Transformations at high pressures and high temperatures: applications to geophysical and petrological problems, Abstracts of the second JapanUSSR Symposium, Misasa, 48-50, 1989.

Liu, M., and C.G. Chase, Evolution of midplate hot spot swells: numerical solutions, J. Geophys. Res., 94, 5571-5584, 1989.

Longhi, J., Liquidus equilibria and solid solution in the system $\mathrm{CaAl}_{2} \mathrm{Si}_{2} \mathrm{O}_{8}-\mathrm{Mg}_{2} \mathrm{SiO}_{4}-\mathrm{CaSiO}_{3}-\mathrm{SiO}_{2}$ at low pressure, $A m$. J. Sci., 287, 265-331, 1987.

Maaloc, S., and K. Aoki, The major element composition of the upper mantle estimated from the composition of lherzolites, Contrib. Mineral. Petrol., 63, 161-173, 1977.

McCulloch, M.T., and W. Compston, Sm-Nd age of Kambalda and Kanowna greenstones and heterogeneity in the Archaean mantle, Nature, 294, 322-327, 1981.

McFarlane, E.A., M.J. Drake, and C. T. Herzberg, Magnesiowustite/ melt and majorite/melt partitioning and the early thermal history of the Earth, (abstract), Proc. Lunar Planet Sci. Conf., 22, 1990.

McKenzie, D.P., The generation and compaction of partial molten rock, J. Petrol., 25, 713-765, 1984.

McKenzie, D., and M.J. Bickle, The volume and composition of melt generated by extension of the lithosphere, J. Petrol., 29, 625-679, 1988.

Miller, G.H., E.M. Stolper, and T.J. Ahrens, The equation of state of a molten komatiite, 1 , Shock wave compression to $36 \mathrm{GPa}, J$. Geophys. Res., 96, 11,831-11,848, 1991 a.

Miller, G.H., E.M. Stolper, and T.J. Ahrens, The equation of state of a molten komatiite, 2, Application to komatiite petrogenesis and the Hadean mantle, J. Geophys. Res., 96, 11,849-11,864, $1991 b$.

Mysen, B.O., and I. Kushiro, Compositional relations of coexisting phases with degree of melting of peridotite in the upper mantle, $A m$. Mineral., 62, 843-865, 1977.

Nesbitt, R.W., and S.-S. Sun, Geochemistry of Archaean spinifextextured peridotites and magnesian and low-magnesian tholeiites, Earth Planet. Sci.. Lett., 31, 433-453, 1976.

Nesbitt, R.W., S.-S. Sun, and A.C. Purvis, Komatiites: geochemistry and genesis, Can. Muneral., 17, 165-186, 1979.

Nisbet, E.G., N.T. Arndt, M.J. Bickle, W.E. Cameron, C. Chavel, M. Cheadle, E. Hegner, T.K. Kyser, A. Martin, R. Renner, and E. Roeddler, Uniquely fresh $2.7 \mathrm{Ga}$ komatites from the Belingwe greenstone belt, Zimbabwe, Geology, 15, 1147-1150, 1987.

Nisbet, E.G., and D. Walker, Komatiites and the structure of the Archaean mantle, Earth Planet. Sci. Lett., 60, 105-113, 1982.

Obata, M., and J.S. Dickey Jr., Phase relations of mafic layers in the Ronda Peridotile, Year Book Camegie Inst. Washington, 75, 562-566, 1976.

O'Hara, M.J., The bearing of phase equilibria studies in synthetic and natural systems on the origin and evolution of basic and ultrabasic rocks, Earth Sci. Rev., 4, 69-133, 1968.

O'Hara, M.J., and H.S. Yoder, Jr., Formation and fractionation of basic magmas at high pressures, Scott. J. Geol., 3, 67-117, 1967.

O'Hara, M.J., M.J. Saunders, and E.P.L. Mercy, Garnet-peridotite, primary ultrabasic magma and eclogites; interpretation of upper mantle processes in kimberlite, Phys. Chem. Earth, 9, 571-604, 1975.

Ohtani, E., Generation of komatiite magma and gravitational differentiation in the deep upper mantle, Earth Planet. Sci. Lett, 67, 261-272, 1984.

Ohtani, E., I. Kawabe, J. Moriyama, and Y. Nagata, Partitioning of elements between majorite garnet and melt and implications for pelrogenesis of komatiite, Contrib. Mineral. Petrol., 103, 263-269, 1989.

Presnall, D.C., and T. Gasparik, Melting of enstatite $\left(\mathrm{MgSiO}_{3}\right)$ from 10 to 16.5 GPa and the forsterile $\left(\mathrm{Mg}_{2} \mathrm{SiO}_{4}\right)$ - majorite $\left(\mathrm{MgSiO}_{3}\right)$ eutectic at $16.5 \mathrm{GPa}$ : implications for the origin of the mantle, J. Geophys. Res., 95, 15,771-15,778, 1990.

Presnall, D.C., J.R. Dixon, T.H. O'Donnell, and S.A. Dixon, Generation of mid-ocean ridge tholeiites, J. Petrol., 20, 3-35, 1979.

Pyke, D.R., A.J. Naldrett, and O.R. Eckstrand, Archean ultramafic flows in Munro Township, Ontario, Geol. Soc. Am. Bull., 84, 955978, 1973.

Reed, M.H., Seawater-basalt reaction and the origin of greenstones and related ore deposits, Econ. Geol., 78, 466-485, 1983.

Salters, V.J.M., and S.R. Hart, The hafnium paradox and the role of garnet in the source of mid-ocean-ridge basalts, Nature, 342, 420$422,1989$.

Shirey, S.B., and G.N. Hanson, Mantle heterogeneity and crustal recycling in Archean granite-greenstone belts: evidence fiom $\mathrm{Nd}$ isotopes and trace elements in the Rainy Lake area, Superior Province, Ontario, Canada, Geochim. Cosmochim. Acta, 50, 2631$2651,1986$.

Sleep, N., Hotspots and mantle plumes: some phenomenology, $J$. Geophys. Res., 95, 6715-6736, 1990.

Smith, A.D, and J.N. Ludden, Nd isotopic evolution of the precambrian mantle, Earth Planet. Sci. Lett., 93, 14-22, 1989.

Smith, H.S., and A.J. Erlank, Geochemistry and petrogenesis of 
komatiites from the Barberton greenstone belt, South Africa, In: Komatiites, edited by N.T. Arndt and E.G. Bickle, pp. 347-397, George Allen and Unwin, London, 1982.

Stevenson, D.J., Origin of the moon - the collision hypothesis, Annu. Rev. Earth Planet. Sci. 15, 271-315, 1987.

Storey, M., J.J. Mahoney, L.W. Kroenke, and A.D. Saunders, Are oceanic plateaus sites of komatiite formation?, Geology, 19, 376-379, 1991.

Stosch, H.-G., and H.A. Seck, Geochemistry and mineralogy of two spinel peridotite suites from Dreiser Weiher, West Germany, Geochim. Cosmochim. Acta, 44, 457-470, 1980.

Sun, S.-S., and R.W. Nesbitt, Petrogenesis of Archaean ultrabasic and basic volcanics: evidence from rare earth elements, Contrib. Mineral. Petrol., 65, 301-325, 1978.

Takahashi, E., Melting of a dry peridotite KLB-1 up to $14 \mathrm{GPa}$ : Implications on the origin of peridotitic upper mantle, J. Geophys. Res., 91, 9367-9382, 1986.

Takahashi, E., Speculations on the Archean mantle: missing link between komatiite and depleted garnet peridotite, J. Geophys. Res., 95, 15, 941-15, 954, 1990.

Takahashi, E., and I. Kushiro, Melting of a dry peridotite at high pressures and basalt magma genesis, Am. Mineral., 68, 859-879, 1983.

Tarduno, J.A., W.V. Sliter, L. Kroenke, M. Leckie, H. Mayer, J.J. Mahoney, R. Musgrave, M. Storey, and E.L. Winterer, Rapid formation of Ontong Java plateau by Aptian mantle plume volcanism, Science, 254, 399-403, 1991.

Taylor, H.J.C., Melting in the system $\mathrm{MgO}-\mathrm{Al}_{2} \mathrm{O}_{3}-\mathrm{SiO}_{2}$ at $15 \mathrm{~kb}$, Geol. Soc. Am. Bull., 84, 1335-1348, 1973.
Turcotte, D.L., On the thermal evolution of the Earth, Earth Planet. Sci. Lett., 48, 53-58, 1980.

Viljoen, R.P., and M.J. Viljoen, Evidence for the composition of the primitive mantle and its products of partial melting from a study of the rocks of the Barberton Mountain Land, Geol. Soc. S. Afr. Spec. Publ., 2, 275-296, 1969.

Von Damm, K.L., J.M. Edmond, B. Grant, C.I. Measures, B. Walden, and R.F. Weiss, Chemistry of submarine hydrothermal solutions at $21^{\circ} \mathrm{N}$, East Pacific Rise, Geochim. Cosmochim. Acta, 49, 2197-2220, 1985.

Walker, R.J., L.M. Echeverria, S.B. Shirey, and M.F. Horan, Re-Os isotopic constraints on the origin of volcanic rocks, Gorgona Island, Colombia: Os isotopic evidence for ancient heterogeneities in the mantle, Contrib. Mineral. Petrol., 107, 150-162, 1991.

Watson, S., and D. McKenzie, Melt generation by plumes: a study of Hawaiian volcanism, J. Petrol., 32, 501-537, 1991.

Wei, K., R.G. Tronnes, and C.M. Scarfe, Phase relations of aluminumundepleted and aluminum-depleted komatiites at pressures of 4-12 GPa, J. Geophys. Res., 95, 15,817-15,828, 1990.

Wetherill, G., Formation of the Earth, Annu. Rev. Earth Planet. Sci., 18, 205-256, 1990.

C. Herzberg, Department of Geological Sciences, Rutgers University, Wright Laboratory, Busch Campus, New Brunswick, NJ 08903.

(Received March 31, 1991;

revised November 18, 1991

accepted December 10, 1991.) 